\title{
Mode of oral iron administration and the amount of iron habitually consumed do not affect iron absorption, systemic iron utilisation or zinc absorption in iron-sufficient infants: a randomised trial
}

\author{
Ewa A. Szymlek-Gay ${ }^{1}{ }^{*}+$, Magnus Domellöf ${ }^{1}$, Olle Hernell $^{1}$, Richard F. Hurrell ${ }^{2}$, Torbjörn Lind ${ }^{1}$, \\ Bo Lönnerdal ${ }^{3}$, Christophe Zeder $^{2}$ and Ines M. Egli ${ }^{2} \ddagger$ \\ ${ }^{1}$ Department of Clinical Sciences, Pediatrics, Umeå University, SE-901 85 Umeå, Sweden \\ ${ }^{2}$ Laboratory of Human Nutrition, Institute of Food, Nutrition and Health, ETH Zurich, CH-8092 Zurich, Switzerland \\ ${ }^{3}$ Department of Nutrition, University of California, Davis, CA 95616, USA
}

(Submitted 9 May 2016 - Final revision received 15 July 2016 - Accepted 18 July 2016)

Abstract

Different metabolic pathways of supplemental and fortification Fe, or inhibition of $\mathrm{Zn}$ absorption by Fe, may explain adverse effects of supplemental Fe in Fe-sufficient infants. We determined whether the mode of oral Fe administration or the amount habitually consumed affects Fe absorption and systemic Fe utilisation in infants, and assessed the effects of these interventions on $\mathrm{Zn}$ absorption, Fe and $\mathrm{Zn}$ status, and growth. Fe-sufficient 6-month-old infants $(n 72)$ were randomly assigned to receive $6.6 \mathrm{mg} \mathrm{Fe} / \mathrm{d}$ from a high-Fe formula, $1.3 \mathrm{mg}$ Fe/d from a low-Fe formula or $6.6 \mathrm{mg} \mathrm{Fe} / \mathrm{d}$ from Fe drops and a formula with no added Fe for $45 \mathrm{~d}$. Fractional Fe absorption, Fe utilisation and fractional $\mathrm{Zn}$ absorption were measured with oral $\left({ }^{57} \mathrm{Fe}\right.$ and $\left.{ }^{67} \mathrm{Zn}\right)$ and intravenous $\left({ }^{58} \mathrm{Fe}\right.$ and $\left.{ }^{70} \mathrm{Zn}\right)$ isotopes. Fe and $\mathrm{Zn}$ status, infection and growth were measured. At $45 \mathrm{~d}$, Hb was $6.3 \mathrm{~g} / \mathrm{l}$ higher in the high-Fe formula group compared with the Fe drops group, whereas serum ferritin was 34 and $35 \%$ higher, respectively, and serum transferrin $0 \cdot 1 \mathrm{~g} / 1$ lower in the high-Fe formula and Fe drops groups compared with the low-Fe formula group (all $P<0 \cdot 05$ ). No intervention effects were observed on Fe absorption, Fe utilisation, Zn absorption, other Fe status indices, plasma Zn or growth. We concluded that neither supplemental or fortification Fe nor the amount of Fe habitually consumed altered Fe absorption, Fe utilisation, $\mathrm{Zn}$ absorption, Zn status or growth in Fe-sufficient infants. Consumption of low-Fe formula as the only source of Fe was insufficient to maintain Fe stores.

Key words: Infants: Iron absorption: Zinc absorption: Iron utilisation: Infant formula: Iron supplements: Randomised trials

Fe deficiency is a major public health problem worldwide ${ }^{(1)}$. Infants aged >4-6 months are at particular risk as their dietary Fe intakes are often insufficient to support increased physiological requirements during rapid growth. Fe-deficiency anaemia in early childhood has been associated with long-lasting and potentially irreversible cognitive and behavioural delays ${ }^{(2)}$. Provision of an adequate amount of Fe in infancy is therefore essential to reduce the risk of deficiency and avoid its negative effects. Both Fe supplements ${ }^{(3-6)}$ and Fe-fortified formula ${ }^{(7-11)}$ have been effective in improving Fe status and reducing the prevalence of Fe deficiency in young children. However, concerns have been raised about $\mathrm{Fe}$ supplementation of Fe-sufficient infants, including reduced infant growth ${ }^{(5,6,12,13)}$ and increased morbidity ${ }^{5,13)}$.

Fe supplements and fortification Fe appear to follow different metabolic pathways in infants, as supplemental Fe has been shown to be stored in ferritin, whereas fortification Fe seems to be utilised for $\mathrm{Hb}$ synthesis ${ }^{(14)}$. The different targeting has been suggested to be due to the high absorption rate of supplemental
$\mathrm{Fe}^{(15)}$, which is often provided in a single daily dose without food. This can result in a high postabsorptive peak in serum Fe, which mobilises hepcidin to divert Fe to storage ${ }^{(14)}$. High peaks in serum Fe may also lead to an increase in circulating nontransferrin-bound $\mathrm{Fe}^{(16)}$, resulting in the production of reactive oxygen species $^{(17)}$. Fe-mediated oxidative stress has been proposed to be responsible for the negative effects of excessive Fe supplementation, as suggested by findings in a mouse model $^{(18)}$. Recently, however, high-Fe-fortified foods consumed in infancy have also been shown to adversely affect the longterm neurodevelopment of children with initially high $\mathrm{Hb}$ concentrations $(>128 \mathrm{~g} / \mathrm{l})^{(19)}$ and increase morbidity in settings with high rates of infection ${ }^{(20)}$. The mechanisms behind these observations are still unknown, making it difficult to design effective yet safe programmatic strategies for the prevention of Fe deficiency in early childhood.

The adverse effects of Fe supplements or high-Fe-fortified foods on infant health and development may possibly be

* Corresponding author: E. A. Szymlek-Gay, fax +61392446017, email ewa.szymlekgay@deakin.edu.au

$\dagger$ Present address: Institute for Physical Activity and Nutrition (IPAN), School of Exercise and Nutrition Sciences, Deakin University, Geelong, Australia

‡ Present address: ETH Board, Zurich, Switzerland. 
mediated through the negative effect of Fe on $\mathrm{Zn}$ absorption and subsequently $\mathrm{Zn}$ status ${ }^{(21)}$. Alternatively, the impairment in $\mathrm{Zn}$ status due to $\mathrm{Fe}$ intakes may occur after absorption, as excessive Fe intakes can lead to an increase in circulating nontransferrin-bound $\mathrm{Fe}^{(16)}$, which can induce the formation of reactive oxygen species and an immune response ${ }^{(17)}$, and consequently result in a decline in plasma $\mathrm{Zn}$ concentration ${ }^{(22)}$. Inadequate $\mathrm{Zn}$ status has been associated with impaired growth, poor immune function and compromised neurobehavioural function $^{(23-25)}$. Zn absorption, however, appears to be reduced by $\mathrm{Fe}$ only when both minerals are provided together as a supplement in aqueous solutions and in disproportionate molar doses ${ }^{(21,26)}$. Whether Fe supplements given alone compromise infant $\mathrm{Zn}$ nutrition is still unclear ${ }^{(21,27-29)}$. When present as a fortificant, Fe does not appear to inhibit $\mathrm{Zn}$ absorption $^{(30-32)}$, impair Zn status ${ }^{(32-34)}$ or result in measurable circulating non-transferrin-bound $\mathrm{Fe}^{(16)}$. Few studies, however, have addressed this in infants. Thus, the aim of this study was to determine whether the mode of oral Fe administration (i.e. Fe supplementation $v$. fortification $\mathrm{Fe}$ ) or the amount of Fe habitually consumed (i.e. high $v$. low $\mathrm{Fe}$ intakes) affects $\mathrm{Fe}$ absorption and systemic Fe utilisation in healthy, term, Fe-sufficient 6-month-old infants. We also determined the effects of these interventions on $\mathrm{Zn}$ absorption and the indicators of Fe and $\mathrm{Zn}$ status, as well as growth.

\section{Methods}

\section{Study design and participants}

This was a 45-d, partial double-blind (formula groups blinded), parallel, three-group, randomised intervention trial with a 1:1:1 participant allocation ratio. The trial was conducted from October 2010 to May 2012 in Umeå, Sweden. Infants were identified through the Swedish population register, and all those residing locally and aged 5-6 months during the recruitment period (October 2010-March 2012) were invited to participate. Infants were eligible for the trial if they were healthy, 6 months old at baseline and had been predominantly formula-fed before enrolment. Infants were excluded if they were (1) born preterm ( $<37$ weeks of gestation), (2) had low birth weight $(<2500 \mathrm{~g})$, (3) had a baseline $\mathrm{Hb}$ concentration $<100 \mathrm{~g} / 1$, (4) had a baseline serum ferritin concentration $<12 \mu \mathrm{g} / \mathrm{l}$, (5) had illness or consumed medications known to interfere with Fe or Zn absorption, (6) had ever received $\mathrm{Fe}$ medications or supplements, (7) were currently consuming Zn supplements or (8) had feeding problems. Previous use of Fe-fortified infant formula or Fe-fortified infant foods did not preclude participation in the trial. This study was conducted according to the guidelines laid down in the Declaration of Helsinki, and all procedures were approved by the Ethics Committees of Umeå University (Umeå, Sweden) and ETH Zurich (Zurich, Switzerland). Written informed consent was obtained from both parents of all participating infants. This trial was registered at www.clinicaltrials.gov as NCT01216709.

\section{Sample size}

Sample size calculations were based on previous data on the incorporation of Fe-stable isotopes into erythrocytes in infants $^{(35)}$. Assuming an SD of $0 \cdot 25$ for log-transformed incorporation data, we estimated that twenty-one infants were required per group to detect a $40 \%$ difference in incorporation of Fe into erythrocytes between any two groups with $80 \%$ power and a two-sided $\alpha$ of $5 \%$. Allowing for approximately $15 \%$ attrition, twenty-four infants were enrolled in each group. The sample size calculated on the basis of this difference in incorporation of $\mathrm{Fe}$ into erythrocytes also allowed $80 \%$ power and a two-sided $\alpha$ of $5 \%$ to detect a $30 \%$ difference in $\mathrm{Zn}$ absorption between any two groups, with the assumption of an SD of $11 \cdot 0 \%{ }^{(36)}$.

\section{Randomisation and blinding}

A computer-generated, permuted-block (block size, $n$ 3) randomisation sequence with stratification by sex was used to randomly assign seventy-two eligible infants to one of three groups: high-Fe formula ( $n$ 24), low-Fe formula ( $n$ 24) or Fe drops ( $n$ 24); three-digit codes were used to indicate the treatment groups. Infants were enrolled and assigned to the interventions by two paediatric research nurses who were blinded to the allocation sequence. Allocation concealment was achieved via secure storage of the randomisation sequence separately from the participant database. Neither the trial participants nor the researchers were aware of the formula group assignment. The codes were broken when data collection, biochemical analyses and data entry were completed.

\section{Interventions and adherence}

For the duration of this 45-d study, parents were asked to feed their infant daily (except for day 31: Fe and $\mathrm{Zn}$ absorption test day) $534 \mathrm{ml}$ of high-Fe formula (high-Fe formula group), low-Fe formula (low-Fe formula group) or formula with no added $\mathrm{Fe}$ (Fe drops group). The formulae were identical in appearance, taste and composition with the exception of Fe content. The formulae were manufactured by Semper AB, Sweden, and had the following analysed nutrient content: $12.4 \mathrm{mg} \mathrm{Fe}$ as ferrous sulphate/l (95.0 mg Fe/kg powdered formula), $3.9 \mathrm{mg} \mathrm{Zn} / \mathrm{l}$, $132.0 \mathrm{mg}$ ascorbic acid/l and $13.4 \mathrm{~g}$ protein/l in the high-Fe formula; $2.3 \mathrm{mg} \mathrm{Fe}$ as ferrous sulphate $/ 1$ (18.0 mg Fe/kg pow-

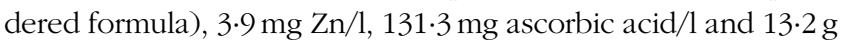
protein/l in the low-Fe formula; and $0.5 \mathrm{mg} \mathrm{Fe} / 1$ ( $4.0 \mathrm{mg} \mathrm{Fe} / \mathrm{kg}$ powdered formula), $3.8 \mathrm{mg} \mathrm{Zn} / 1,131.3 \mathrm{mg}$ ascorbic acid/1 and $13.1 \mathrm{~g}$ protein/l in the formula with no added Fe. The formulae were packaged into identical foil bags. The bags were marked with only the three-digit randomisation code. The formulae were provided to the parents as powder in pre-weighed daily portions of $69.5 \mathrm{~g}$. Parents were asked to mix this quantity of formula with $480 \mathrm{ml}$ of water. To ensure correct formula dilutions, parents were given a 500-ml graduated cylinder to assist with the measuring of water. Each parent was asked to feed their infant the assigned formula as three meals each day. Parents of infants in the Fe drops group were also asked to give their child $0.42 \mathrm{ml}$ of oral Fe drops daily in a single dose (except for day 31: Fe and $\mathrm{Zn}$ absorption test day) between meals for the duration of the study $(15.0 \mathrm{mg}$ Fe as ferrous sulphate $/ \mathrm{ml}$; Ferrous Sulfate Iron Supplement Drops; Hi-Tech Pharmacal Co. Inc.). To allow for accurate administration of Fe 
drops, parents were given a $1-\mathrm{ml}$ graduated oral syringe. The assigned quantity of study formulae (i.e. $534 \mathrm{ml} / \mathrm{d}$ of either highFe or low-Fe formula, depending on the infants' group assignment) provided infants in the high-Fe formula group with $6.6 \mathrm{mg} \mathrm{Fe} / \mathrm{d}$ and infants in the low-Fe formula group with $1.3 \mathrm{mg} \mathrm{Fe} / \mathrm{d}$. The formula with no added Fe (i.e. $534 \mathrm{ml} / \mathrm{d}$ ) and Fe drops (i.e. $0.42 \mathrm{ml} / \mathrm{d}$ ) provided infants in the Fe drops group with $6.6 \mathrm{mg} \mathrm{Fe} / \mathrm{d}$. During the study, infants were not permitted to consume $\mathrm{Fe}$ - or $\mathrm{Zn}$-fortified commercial infant foods, nonstudy infant formula, Fe- or Zn-fortified foods, animal tissuecontaining foods, or Fe- or Zn-containing supplements. Infants were allowed to consume ad libitum the following foods provided by the study: infant formula with no added Fe $(0.5 \mathrm{mg}$ $\mathrm{Fe} / \mathrm{l}$; Semper $\mathrm{AB}$ ), rice porridge with no added Fe (Oldana AB) and a range of commercially made fruit- and vegetable-based infant foods with no added Fe or $\mathrm{Zn}$ and free from animal tissue (Semper AB). Parents were also permitted to feed their infants home-made fruit and vegetable purées. Mothers were able to continue to breast-feed at their discretion.

Adherence to the intervention was assessed by asking each parent to record daily the amount of formula consumed by their infant. Parents of infants in the Fe drops group were also asked to record the volume of drops given to their infant each day and note any case of vomiting or posseting by their infant up to $30 \mathrm{~min}$ after the administration of the drops. The adherence data were used to estimate mean daily intakes of study formulae, Fe drops, and $\mathrm{Fe}$ and $\mathrm{Zn}$ intakes from the interventions.

\section{Socio-demographic, anthropometric, obstetric and neonatal data}

Socio-demographic data were collected at baseline using a selfadministered questionnaire. Nude weight was measured to the nearest $5 \mathrm{~g}$ with digital baby scales (Seca 727; Seca Deutschland). Recumbent length was measured to the nearest $0.1 \mathrm{~cm}$ with a paediatric length board (CMS Weighing Equipment Ltd). A nonstretchable measuring tape for head circumference of babies and toddlers (Seca 212; Seca Deutschland) was used to assess each child's head circumference to the nearest $0 \cdot 1 \mathrm{~cm}$. Knee-heel length was measured to the nearest $0 \cdot 1 \mathrm{~cm}$ with an infant knemometer (BK5; FORCE Instituttet). All measurements were taken in accordance with standardised procedures ${ }^{(37)}$. Weight, length and head circumference were measured in duplicate, whereas knee-heel length was measured four times at baseline and at the end of the study. Additional duplicate measurements were taken for weight on day 31. The $z$ scores for weight-for-age, length-for-age and head circumference-for-age were calculated using the World Health Organization Child Growth Standards ${ }^{(38)}$. Obstetric and neonatal data were obtained from hospital records.

\section{Preparation and administration of isotopes}

Fe absorption, systemic Fe utilisation and $\mathrm{Zn}$ absorption were measured using stable-isotope methods. ${ }^{57} \mathrm{Fe}$ (97.8\% enrichment), ${ }^{58} \mathrm{Fe}$ (99.5\% enrichment), ${ }^{67} \mathrm{ZnO}$ (90.6\% enrichment) and ${ }^{70} \mathrm{ZnO}$ (95.4\% enrichment) were purchased from Chemgas. All isotopic labels were prepared at the Human Nutrition Laboratory at ETH Zurich. ${ }^{57} \mathrm{FeSO}_{4}$ for oral administration was prepared by dissolving ${ }^{57} \mathrm{Fe}$ in diluted $\mathrm{H}_{2} \mathrm{SO}_{4}$. The solution was divided into vials containing $0.67 \mathrm{mg}{ }^{57} \mathrm{Fe}$ (administered to the formula groups) or $2 \mathrm{mg}{ }^{57} \mathrm{Fe}$ (administered to the Fe drops group) in $0.5 \mathrm{ml}$ of solution. ${ }^{67} \mathrm{ZnSO}_{4}$ for oral administration was prepared by dissolution of ${ }^{67} \mathrm{ZnO}$ in stoichiometric amounts of diluted $\mathrm{H}_{2} \mathrm{SO}_{4}$. The resulting ${ }^{67} \mathrm{ZnSO}_{4}$ solution was subsequently diluted to a $\mathrm{Zn}$ concentration of $0.33 \mathrm{mg} / \mathrm{g}$ and then aliquoted into vials containing $0.17 \mathrm{mg}{ }^{67} \mathrm{Zn}$ in $0.5 \mathrm{ml}$ of solution. $\left[{ }^{58} \mathrm{Fe}\right]$ citrate was prepared for intravenous infusion from ${ }^{58} \mathrm{Fe}$ as previously described ${ }^{(39)}$. The solution was aliquoted into vials containing $50 \mu \mathrm{g}{ }^{58} \mathrm{Fe}$ in $1 \mathrm{ml}$ of solution. ${ }^{70} \mathrm{ZnCl}_{2}$ was prepared for intravenous infusion by converting ${ }^{70} \mathrm{ZnO}$ to ${ }^{70} \mathrm{ZnCl}_{2}$ with diluted $\mathrm{HCl}$ adjusted to $\mathrm{pH} 6$ by adding $\mathrm{NaHCO}_{3}$ and diluted by physiological saline to a final $\mathrm{Zn}$ concentration of $100 \mu \mathrm{g} / \mathrm{g}$. The solution was then divided into vials containing $100 \mu \mathrm{g}{ }^{70} \mathrm{Zn}$ in $1 \mathrm{ml}$ of solution. All vials containing ${ }^{58} \mathrm{Fe}$ and ${ }^{70} \mathrm{Zn}$ were sterilised and checked for sterility and pyrogens at the Cantonal Pharmacy of the University Hospital Zurich.

The isotopes were administered to each infant at $7 \cdot 3$ months of age (ranging from 6.9-7.8 months) on study day 31. The high-Fe formula, formula with no added Fe and Fe drops used on the day of testing were the same as the ones used for the intervention as described above. The formula (either high-Fe formula or formula with no added $\mathrm{Fe}$, depending on the infant's group assignment) was prepared freshly on the day of testing.

Infants in both formula groups received three meals of $150 \mathrm{ml}$ of high-Fe formula; $0.67 \mathrm{mg}{ }^{57} \mathrm{Fe}$ and $0.17 \mathrm{mg}{ }^{67} \mathrm{Zn}$ were added to each meal $\left(2 \mathrm{mg}{ }^{57} \mathrm{Fe}\right.$ and $0.5 \mathrm{mg}{ }^{67} \mathrm{Zn}$ in total for all three meals) before feeding. The first meal was administered after a 2 -h fast, with the second and third meal fed to infants $2 \mathrm{~h}$ after the previous meal had been ingested. Each meal was fed under standardised conditions over 15-20 min. After each meal, $6 \mathrm{ml} \times 2$ of unlabelled high-Fe formula was administered to each infant to rinse out the bottle. The bottle was weighed immediately before and after feeding. All spills, posseting and other accidental milk losses were removed with pre-weighed napkins. The amount of ${ }^{57} \mathrm{Fe}$ and ${ }^{67} \mathrm{Zn}$ consumed by each infant was calculated by subtracting the amount of ${ }^{57} \mathrm{Fe}$ and ${ }^{67} \mathrm{Zn}$ corresponding to the amount of meal left in the bottle and absorbed in the napkins from the original doses of $0.67 \mathrm{mg}{ }^{57} \mathrm{Fe}$ and $0.17 \mathrm{mg}{ }^{67} \mathrm{Zn}$. Next, $30 \mathrm{~min}$ after the first meal had been ingested, $1 \mathrm{ml}$ of an aqueous solution containing $50 \mu \mathrm{g}{ }^{58} \mathrm{Fe}$ and $1 \mathrm{ml}$ of an aqueous solution containing $100 \mu \mathrm{g}{ }^{70} \mathrm{Zn}$ were aspirated into a syringe, injected into a $25-\mathrm{ml}$ infusion bag ( $0.9 \%$ saline) and infused over $30 \mathrm{~min}$ into each infant in the formula groups. The rate of intravenous infusion of Fe was based on the estimated $2 \mu \mathrm{g} / \mathrm{min}$ plasma appearance of $\mathrm{Fe}$ normally absorbed from the gastrointestinal tract ${ }^{(40)}$. At completion of the infusion, $5 \mathrm{ml}$ of unlabelled saline was injected into the bag to rinse it out and the saline was infused into the infant. This was carried out twice, and we assumed that no residual isotopes remained in the infusion bag.

Infants in the Fe drops group followed a similar protocol as the formula groups. The Fe drops group received three meals of $150 \mathrm{ml}$ of formula with no added Fe; $0 \cdot 17 \mathrm{mg}{ }^{67} \mathrm{Zn}$ was added to each meal $\left(0.5 \mathrm{mg}{ }^{67} \mathrm{Zn}\right.$ in total for all three meals) before feeding. The first meal was administered after a 2-h fast. Next, $2 \mathrm{~h}$ after the first test meal had been ingested, infants in the Fe drops group were administered $0.4 \mathrm{ml}$ of Fe drops labelled with $2 \mathrm{mg}$ 
${ }^{57} \mathrm{Fe}$; $30 \mathrm{~min}$ after the administration of Fe drops, $1 \mathrm{ml}$ of an aqueous solution containing $50 \mu \mathrm{g}{ }^{58} \mathrm{Fe}$ and $1 \mathrm{ml}$ of an aqueous solution containing $100 \mu \mathrm{g}{ }^{70} \mathrm{Zn}$ were aspirated into a syringe, injected into a $25-\mathrm{ml}$ infusion bag ( $0.9 \%$ saline) and infused over $30 \mathrm{~min}$ into each infant in the Fe drops group. At completion of the infusion, $5 \mathrm{ml} \times 2$ of unlabelled saline was injected into the infusion bag to rinse it out, and the saline was infused into the infant; we assumed that no residual isotopes remained in the infusion bag. Immediately following administration of the intravenous dose, infants were fed the second meal with the third one fed to infants $2 \mathrm{~h}$ after the second meal had been ingested. Each meal was fed under standardised conditions over 15-20 min. After each meal, $6 \mathrm{ml} \times 2$ of unlabelled formula with no added $\mathrm{Fe}$ was administered to each infant to rinse out the bottle. The bottle was weighed immediately before and after feeding. All spills, posseting and other accidental milk losses were removed with pre-weighed napkins. The amount of ${ }^{67} \mathrm{Zn}$ consumed by each infant was calculated by subtracting the amount of ${ }^{67} \mathrm{Zn}$ corresponding to the amount of meal left in the bottle and absorbed in the napkins from the original dose of $0.17 \mathrm{mg}$.

Neither the formula groups nor the Fe drops group was permitted to consume any food or drink on the day of testing until $2 \mathrm{~h}$ after the third meal had been ingested. On the day of testing, the formula groups received a total of $8.1 \mathrm{mg} \mathrm{Fe}$ and $2.5 \mathrm{mg} \mathrm{Zn}$, and the Fe drops group received a total of $8.3 \mathrm{mg} F$ and $2.4 \mathrm{mg} \mathrm{Zn}$ (i.e. Fe/Zn in the test meals/Fe drops plus the isotope labels). This amount of $\mathrm{Fe}$ is equivalent to $1 \mathrm{mg} \mathrm{Fe} / \mathrm{kg}$ body weight, assuming a mean body weight of $8 \mathrm{~kg}$ at 7 months $^{(41)}$

\section{Sample collection}

Venous blood samples were drawn at baseline, on day 31 and at the end of the study (day 45) after a 2-h fast for the determination of $\mathrm{Fe}$ and $\mathrm{Zn}$ status indices (each time point), as well as Fe isotopic composition (day 45 samples only). The day 31 samples were collected before the administration of stable isotopes. Samples were collected by experienced paediatric research nurses into an EDTA-containing tube, a serum separator tube and a heparinised trace element-free tube (Becton, Dickinson and Company). The time of sample collection was recorded. Baseline sampling and end-of-study sampling were postponed by 2 weeks if the child was ill or recently immunised to minimise the influence of an acute-phase response on blood indices. A spot urine sample was collected $96 \mathrm{~h}$ after the infusion with stable isotopes and stored at $-20^{\circ} \mathrm{C}$ until $\mathrm{Zn}$ isotopic composition determination ${ }^{(42)}$.

\section{Laboratory analyses}

$\mathrm{Hb}$, mean corpuscular volume, serum ferritin, serum $\mathrm{Fe}$ and serum transferrin were analysed within $2-4 \mathrm{~h}$ of collection at the Department of Clinical Chemistry, Umeå University, Sweden. $\mathrm{Hb}$ and mean corpuscular volume were measured in whole blood using a Sysmex XE-5000 Automated Haematology Analyser (Sysmex). Blood in the serum separator tube was centrifuged for $10 \mathrm{~min}$ at $3000 \mathrm{rpm}$, and the separated serum was analysed for ferritin using a Roche Cobas 6000 (Roche Diagnostics), and $\mathrm{Fe}$ and transferrin were analysed using a
Vitros 5.1 FS (Ortho Clinical, Johnson \& Johnson AB). Values for the controls were within the certified ranges for all analyses. Serum Fe and transferrin concentrations were used to calculate transferrin saturation using the following formula: transferrin saturation $(\%)=$ serum $\mathrm{Fe}(\mu \mathrm{mol} / \mathrm{l}) /(\operatorname{serum}$ transferrin $(\mathrm{g} / \mathrm{l}) \times$ $25 \cdot 1) \times 100^{(43)}$. The remaining serum was stored at $-80^{\circ} \mathrm{C}$ until hepcidin and high-sensitivity $\mathrm{C}$-reactive protein analyses. Hepcidin and high-sensitivity C-reactive protein were determined at the Department of Clinical Sciences, Pediatrics, Umeå University, Sweden, by an enzyme immunoassay using commercial kits (Human Hepcidin Kit S-1337; Bachem AG, and Human C-Reactive Protein, Quantikine ${ }^{\circledR}$ ELISA; R\&D Systems Europe Ltd, respectively). Analytical accuracy was checked by analysing in-house serum controls at low and high concentrations. For hepcidin, the analysed mean values for the quality control sera were 25.9 (SD 2.4; CV 9.3\%; $n$ 5) $\mu \mathrm{g} / 1$ at $25.0 \mu \mathrm{g} / \mathrm{l}$ (low concentration) and $42.8(\mathrm{sD} 5 \cdot 2 ; \mathrm{CV} 12.3 \% ; n$ 5) $\mu \mathrm{g} / \mathrm{l}$ at $40 \cdot 0 \mu \mathrm{g} / \mathrm{l}$ (high concentration). For high-sensitivity C-reactive protein, the analysed mean values for the quality control sera were 154.5 (sD 14.5; CV 9.4\%; $n$ 6) ng/ml at $150 \mathrm{ng} / \mathrm{ml}$ (low concentration) and 3137.7 (SD 202.4; CV 6.4\%;n 6) ng/ml at $3000 \mathrm{ng} / \mathrm{ml}$ (high concentration).

Blood samples in the heparinised trace element-free tube were refrigerated immediately after collection. Plasma was separated within $2 \mathrm{~h}$ and stored at $-80^{\circ} \mathrm{C}$ until $\mathrm{Zn}$ analysis. For day 45 samples, erythrocytes were stored at $-20^{\circ} \mathrm{C}$ for determining $\mathrm{Fe}$ isotopic composition. $\mathrm{Zn}$ concentration and $\mathrm{Fe}$ isotopic composition were measured at the Human Nutrition Laboratory at ETH Zurich. Zn was measured using flame atomic absorption spectrophotometry (Varian AA240FS; Varian Inc.) after dilution with $10 \% \mathrm{HNO}_{3}$ using commercial aqueous standards (Titrisol; Merck) for external calibration. Analytical accuracy was checked by analysis of commercially available serum controls (Seronorm Trace Elements Serum Levels 1 and 2; Sero AS). The analysed mean values for the quality control sera were $25 \cdot 4$ (sD $0 \cdot 6 ; n$ 5) $\mu \mathrm{mol} / \mathrm{l}$ for Level 1 and 31.3 (sD 0.6; $n$ 5) $\mu \mathrm{mol} / 1$ for Level 2 . The certified values were $24 \cdot 1-29 \cdot 2 \mu \mathrm{mol} / 1$ for Level 1 and $27 \cdot 1-47 \cdot 5 \mu \mathrm{mol} / 1$ for Level 2 . The method showed a detection limit of $0.50 \mu \mathrm{mol} / 1$ and its intra-assay and inter-assay CV were 3 and 5\%, respectively. For Fe isotopic analysis, erythrocytes were first mineralised by microwave digestion, and $\mathrm{Fe}$ was then separated by anion-exchange chromatography followed by a solvent-solvent extraction step into diethyl ether ${ }^{(44)}$. $\mathrm{Fe}$ isotopic composition was measured by negative thermal ionisation-MS using a magnetic sector field MS (Finnigan MAT 262; Thermo Finnigan), equipped with a multi-collector system for simultaneous ion beam detection ${ }^{(44)}$. Circulating $\mathrm{Fe}$ was determined for each infant using an assumed blood volume of $65 \mathrm{ml} / \mathrm{kg}^{(45)}$, the measured $\mathrm{Hb}$ concentration and the known concentration of $\mathrm{Fe}$ in $\mathrm{Hb}$ of $3.47 \mathrm{mg} / \mathrm{g}$. Fractional incorporation of ${ }^{57} \mathrm{Fe}$ and ${ }^{58} \mathrm{Fe}$ into erythrocytes $14 \mathrm{~d}$ after isotope administration was calculated according to isotopic dilution principles as described earlier ${ }^{(44)}$. The erythrocyte incorporation of ${ }^{58} \mathrm{Fe}$ indicates Fe utilisation. The absorption of ${ }^{57} \mathrm{Fe}$ was calculated by dividing the percentage of erythrocyte incorporation of ${ }^{57} \mathrm{Fe}$ by the fractional erythrocyte incorporation of ${ }^{58} \mathrm{Fe}$.

Urine samples were analysed for $\mathrm{Zn}$ isotopic composition under chemical blank monitoring at the Human Nutrition 
Laboratory at ETH Zurich. Samples were concentrated by freeze-drying, mineralised by microwave digestion (MLSETHOS plus; MLS GmbH) using a mixture of $\mathrm{HNO}_{3}$ and $\mathrm{H}_{2} \mathrm{O}_{2}$, and $\mathrm{Zn}$ was then separated from the sample matrix by anionexchange chromatography as described previously ${ }^{(46)}$. All acids used for the preparation of samples were ultrapure. ${ }^{70} \mathrm{Zn}$-to- ${ }^{66} \mathrm{Zn}:{ }^{67} \mathrm{Zn}-{ }^{-}{ }^{-}{ }^{66} \mathrm{Zn}$ ratios were measured to determine ${ }^{70} \mathrm{Zn}$ and ${ }^{67} \mathrm{Zn}$ enrichment in the urine samples by inductively coupled plasma MS using a high-resolution, double-focusing, magnetic sector field multi-collector MS (Neptune; ThermoFinnigan). Fractional absorption of ${ }^{67} \mathrm{Zn}$ was calculated from ${ }^{67} \mathrm{Zn}:{ }^{70} \mathrm{Zn}$ ratios as described by Friel et al. ${ }^{(47)}$.

Fe deficiency was defined as depleted Fe stores, Fe-deficient erythropoiesis and Fe-deficiency anaemia ${ }^{(48)}$. Depleted Fe stores were defined as a serum ferritin concentration $<12 \mu \mathrm{g} / \mathrm{l}^{(49)}$ in the absence of Fe-deficient erythropoiesis or Fe-deficiency anaemia. Fe-deficient erythropoiesis was defined as $\geq 2$ abnormal values for serum ferritin $(<12 \mu \mathrm{g} / \mathrm{l})$, mean corpuscular volume $(<71 \mathrm{fl})^{(50)}$ and transferrin saturation $(<10 \%)^{(51)}$ in the absence of anaemia $(\mathrm{Hb} \geq 100 \mathrm{~g} / \mathrm{l})$. Fe-deficiency anaemia was defined as $\mathrm{Hb}<100 \mathrm{~g} / \mathrm{l}^{(50)}$ in the presence of Fe-deficient erythropoiesis. Infants with missing data at each time point for serum ferritin, mean corpuscular volume, transferrin saturation or $\mathrm{Hb}$ were excluded from these estimations. Low plasma $\mathrm{Zn}$ concentration was defined as $<9.9 \mu \mathrm{mol} / 1$ for morning samples and $<8.7 \mu \mathrm{mol} / \mathrm{l}$ for samples drawn afternoon ${ }^{(52)}$. Fe and $\mathrm{Zn}$ deficiency prevalence was estimated after correcting serum ferritin and plasma Zn concentrations for infection for all infants with a C-reactive protein concentration $>5 \mathrm{mg} / \mathrm{l}$ at baseline, day 31 or day 45 ( $n 7$ at baseline, $n 4$ on day 31 and $n 5$ on day 45 ) as described previously $^{(53,54)}$.

\section{Statistical analysis}

The primary outcomes were Fe absorption and systemic Fe utilisation. The secondary outcomes were $\mathrm{Zn}$ absorption and the indices of Fe and $\mathrm{Zn}$ status and growth. Descriptive statistics were used to examine participants' characteristics at birth and baseline. To compare outcomes measured at more than one time point among the three intervention groups (i.e. Fe status indices, plasma $\mathrm{Zn}$ concentration and growth indices), in order to utilise all data, we used linear random-intercept models with robust standard errors where repeated measurements were nested within individuals. All models included fixed effects of time and group and their interaction in order to assess differences in change within and between groups. Adjustments were made for a priori-defined covariates: sex and infection (Fe status indices), time of day of blood sampling and infection (plasma $\mathrm{Zn}$ ), and sex (growth indices). To compare outcomes measured at only one time point among the three groups (i.e. Fe absorption, Fe utilisation and $\mathrm{Zn}$ absorption), we used linear regression analyses with robust standard errors. Linear regression models were used to examine the relationship between Fe absorption and Fe utilisation and Fe status indices at day 31; $\mathrm{Hb}$, mean corpuscular volume, serum $\mathrm{Fe}$, serum transferrin, transferrin saturation and serum hepcidin measures were excluded for all infants with a C-reactive protein concentration $>5 \mathrm{mg} / \mathrm{l}$, whereas serum ferritin was corrected for infection for all infants with a C-reactive protein concentration $>5 \mathrm{mg} / \mathrm{l}^{(53)}$. The distributions of residuals from all models were examined, and logtransformations were used where residuals were skewed or exhibited non-constant variance. Where log-transformations were used, results are shown as ratios of geometric means rather than differences of arithmetic means.

Prevalence of Fe deficiency and low plasma Zn concentration was assessed at three time points, and thus random-intercept logistic regression analyses where repeated measurements were nested within individuals were used to assess group effects.

As infants had up to $45 \mathrm{~d}$ of adherence data, generalised estimating equation models with exchangeable correlation structures were used to assess differences among the study groups in study formula intakes and $\mathrm{Fe}$ and $\mathrm{Zn}$ intakes from the interventions.

All analyses were performed with Stata (version 13.1; StataCorp LP). All tests were two-sided and were not adjusted for multiple testing. Statistical significance was determined at $P<0 \cdot 05$.

\section{Results}

\section{Participants}

Invitation letters, followed up by telephone calls, were sent to parents of 2429 infants. Of these, 160 expressed initial interest in participation and ninety-seven were assessed for eligibility. The screening process identified seventy-two eligible infants who were randomly assigned to one of the three intervention groups (Fig. 1). All infants received their allocated intervention; six infants $(8 \cdot 3 \%)$ were lost to follow-up.

The mean age of infants at baseline was $6 \cdot 1$ (sD $0 \cdot 3$ ) months, and the mean gestational age was $40 \cdot 1$ (SD 1.3) weeks. The majority of infants were boys, were born via vaginal delivery, were not breast-fed at baseline and were from middle-income families. In all, $50 \%$ of mothers had university education. All infants and their mothers were born in Sweden, and all infants' anthropometric birth indices were within the normal range (Table 1).

\section{Adherence to intervention}

The mean amount of study formula consumed during the trial was $516(95 \%$ CI 511,522$) \mathrm{ml} / \mathrm{d}$ in the high-Fe formula group, $508(95 \%$ CI 500,516$) \mathrm{ml} / \mathrm{d}$ in the low-Fe formula group and $503(95 \%$ CI 488, 518) ml/d in the Fe drops group. There was no statistically significant difference among the three groups in the daily amount of study formula consumed during the intervention period $(P=0.092)$.

The required volume of Fe drops (i.e. $0.42 \mathrm{ml} / \mathrm{d}$ ) was administered to infants in the Fe drops group on $99.9 \%$ of occasions. Accounting for vomiting and posseting, $0.42 \mathrm{ml}$ of Fe drops/d were consumed by infants in the Fe drops group on $95.2 \%$ of occasions. This resulted in the Fe drops group consuming a mean of $0.39(95 \%$ CI $0.37,0.42) \mathrm{ml} / \mathrm{d}$ of Fe drops.

During the intervention, the study formulae provided $6.4(95 \% \mathrm{CI} 6.3,6.4) \mathrm{mg} \mathrm{Fe} / \mathrm{d}$ to infants in the high-Fe formula group, and $1.2(95 \% \mathrm{CI} 1 \cdot 2,1 \cdot 2) \mathrm{mg} \mathrm{Fe} / \mathrm{d}$ to infants in the low-Fe formula group. The formula with no added Fe combined 


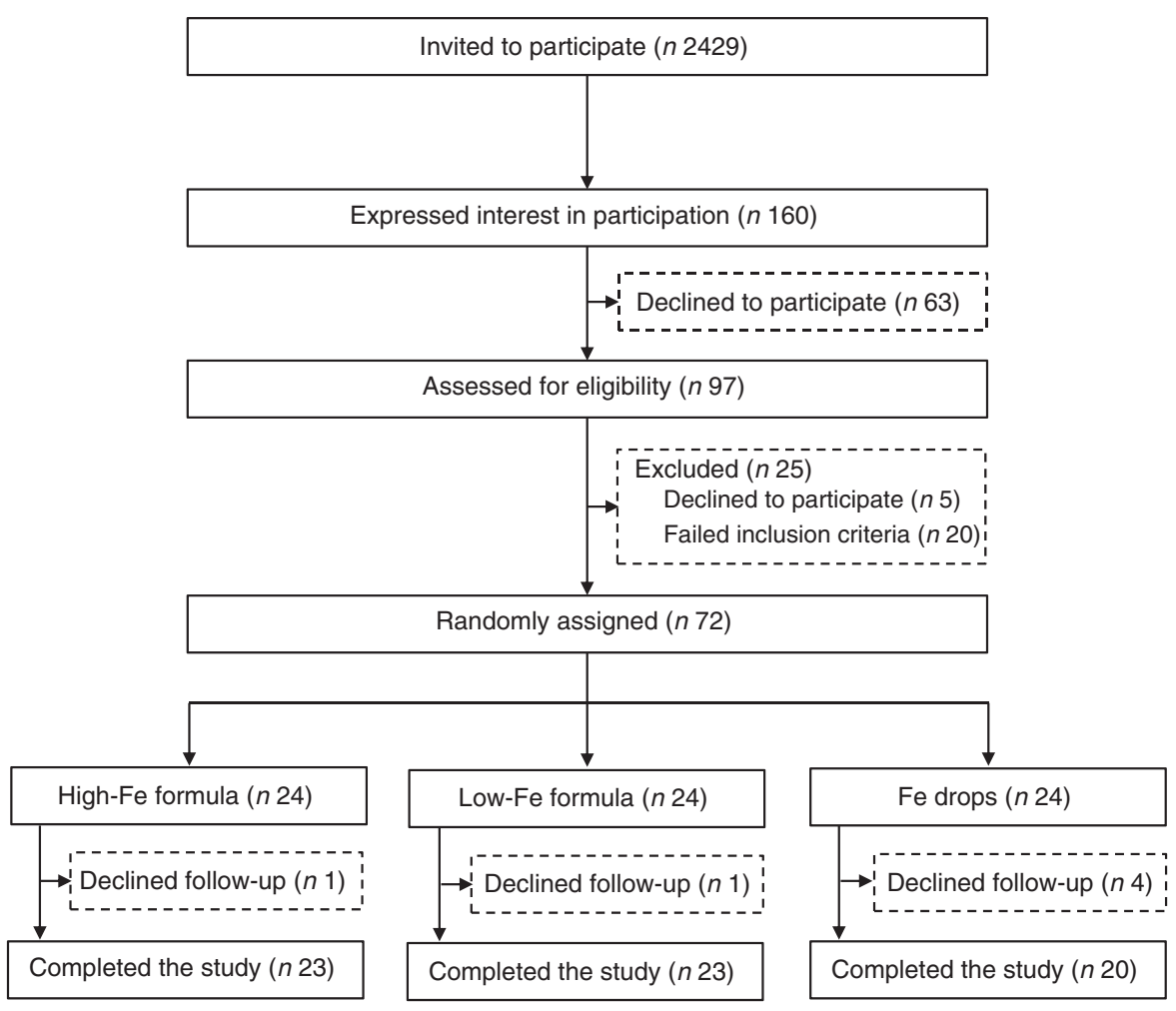

Fig. 1. Flow chart of participants through the study.

Table 1. Characteristics of infants at birth and baseline

(Numbers and percentages; mean values and standard deviations)

\begin{tabular}{|c|c|c|c|c|c|c|}
\hline & \multicolumn{2}{|c|}{ High-Fe formula ( $n$ 24) } & \multicolumn{2}{|c|}{ Low-Fe formula $(n$ 24) } & \multicolumn{2}{|c|}{ Fe drops ( $n$ 24) } \\
\hline & $n$ & $\%$ & $n$ & $\%$ & $n$ & $\%$ \\
\hline \multicolumn{7}{|l|}{ Age (months) } \\
\hline Mean & \multirow{2}{*}{\multicolumn{2}{|c|}{$6 \cdot 1$}} & \multicolumn{2}{|c|}{$6 \cdot 1$} & \multicolumn{2}{|c|}{$6 \cdot 1$} \\
\hline $\mathrm{SD}$ & & & \multicolumn{2}{|c|}{0.3} & \multicolumn{2}{|c|}{0.3} \\
\hline Female & 11 & $45 \cdot 8$ & 11 & $45 \cdot 8$ & 11 & $45 \cdot 8$ \\
\hline Vaginal delivery & 20 & $83 \cdot 3$ & 20 & $83 \cdot 3$ & 22 & 91.7 \\
\hline \multicolumn{7}{|l|}{ Gestational age (weeks) } \\
\hline Mean & \multicolumn{2}{|c|}{39.4} & \multicolumn{2}{|c|}{$40 \cdot 3$} & \multicolumn{2}{|c|}{$40 \cdot 6$} \\
\hline SD & \multicolumn{2}{|c|}{1.3} & \multicolumn{2}{|c|}{1.3} & \multicolumn{2}{|c|}{1.0} \\
\hline \multirow{2}{*}{\multicolumn{7}{|c|}{ Birth weight $(\mathrm{kg})$}} \\
\hline Mean & \multirow{2}{*}{\multicolumn{2}{|c|}{$\begin{array}{l}3.6 \\
0.6\end{array}$}} & \multicolumn{2}{|c|}{$3 \cdot 7$} & & \\
\hline SD & & & & & & \\
\hline \multicolumn{7}{|l|}{ Birth length $(\mathrm{cm})$} \\
\hline Mean & \multicolumn{2}{|c|}{$50 \cdot 3$} & \multicolumn{2}{|c|}{$50 \cdot 8$} & \multicolumn{2}{|c|}{51.5} \\
\hline SD & \multicolumn{2}{|c|}{1.8} & \multicolumn{2}{|c|}{2.1} & \multicolumn{2}{|c|}{1.9} \\
\hline \multicolumn{7}{|l|}{ Birth head circumference $(\mathrm{cm})$} \\
\hline Mean & \multirow{2}{*}{\multicolumn{2}{|c|}{$\begin{array}{r}35.0 \\
1.4\end{array}$}} & \multirow{2}{*}{\multicolumn{2}{|c|}{$\begin{array}{c}35 \cdot 3 \\
1.6\end{array}$}} & \multirow{2}{*}{\multicolumn{2}{|c|}{$\begin{array}{r}35.8 \\
1.3\end{array}$}} \\
\hline SD & & & & & & \\
\hline Breast-fed at baseline & 4 & $16 \cdot 7$ & 2 & 8.3 & 4 & $16 \cdot 7$ \\
\hline Mother and infant born in Sweden & 24 & $100 \cdot 0$ & 24 & $100 \cdot 0$ & 24 & $100 \cdot 0$ \\
\hline Mother with university education & 12 & $50 \cdot 0$ & 14 & $58 \cdot 3$ & 10 & $41 \cdot 7$ \\
\hline \multicolumn{7}{|l|}{ Income ${ }^{*}$} \\
\hline$<$ SEK240 000 & 2 & 8.3 & 8 & $33 \cdot 3$ & 6 & $25 \cdot 0$ \\
\hline SEK240 000-SEK479 999 & 18 & $75 \cdot 0$ & 13 & $54 \cdot 2$ & 14 & $58 \cdot 3$ \\
\hline$\geq$ SEK480 000 & 1 & 4.2 & 2 & $8 \cdot 3$ & 2 & $8 \cdot 3$ \\
\hline
\end{tabular}

with Fe drops provided 5.7 (95\% CI 5.1, 6.3) mg Fe/d to infants in the Fe drops group. Fe intakes from the interventions differed among groups $(P<0.001)$ and were higher in the high-Fe formula group compared with the low-Fe formula group (mean difference: $5.2(95 \% \mathrm{CI} 4.8,5.5) \mathrm{mg} \mathrm{Fe} / \mathrm{d}, P<0.001)$, higher in the high-Fe formula group compared with the Fe drops group 
(mean difference: 0.6 (95\% CI 0.3, 1.0) $\mathrm{mg} \mathrm{Fe} / \mathrm{d}, P=0.001)$ and higher in the Fe drops group compared with the low-Fe formula group (mean difference: 4.6 (95\% CI 4.2, 4.9) $\mathrm{mg} \mathrm{Fe} / \mathrm{d}$, $P<0.001)$.

The high-Fe formula group received $2 \cdot 0$ (95\% CI 2.0, 2.0) $\mathrm{mg}$ $\mathrm{Zn} / \mathrm{d}$, the low-Fe formula group received 2.0 (95\% CI 1.9 , $2.0) \mathrm{mg} \mathrm{Zn} / \mathrm{d}$ and the Fe drops group received 1.9 (95\% CI 1.9 ,

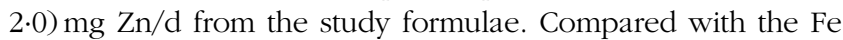
drops group, $\mathrm{Zn}$ intakes from the study formulae were higher in both the high-Fe formula group (mean difference: $0 \cdot 1$ (95\% CI $0 \cdot 1,0.2) \mathrm{mg} \mathrm{Zn} / \mathrm{d}, P<0.001)$ and the low-Fe formula group (mean difference: $0 \cdot 1$ (95\% CI 0.0, 0.1) $\mathrm{mg} \mathrm{Zn/d}, P=0 \cdot 007$ ).

\section{Iron and zinc status}

By $45 \mathrm{~d}$, mean $\mathrm{Hb}$ concentration decreased from baseline by 4.9 $(95 \% \mathrm{CI}-8 \cdot 3,-1.4) \mathrm{g} / \mathrm{l}$ in the Fe drops group with no evidence of a change in the high-Fe formula or low-Fe formula groups (Table 2). Because of the decrease in Hb concentration in the Fe drops group, at the end of the study, there was a significant difference in change in the mean $\mathrm{Hb}$ concentration between the high-Fe formula and Fe drops groups (intervention effect: $6 \cdot 3$ $(95 \% \mathrm{CI} 1.4,11 \cdot 2) \mathrm{g} / \mathrm{l})$. At the end of the study, Hb concentration also tended to be $3.8(95 \% \mathrm{CI}-0.6,8 \cdot 2) \mathrm{g} / \mathrm{l}$ higher in the high-Fe formula group than in the low-Fe formula group $(P=0 \cdot 088)$. Within-group comparisons showed a 32 (95\% CI $22,40) \%$ decrease in mean serum ferritin concentration from baseline in the low-Fe formula group with no evidence for a change in the high-Fe formula or Fe drops groups (Table 2). Compared with the low-Fe formula group, at the end of the study, mean serum ferritin concentration was 34 (95\% CI 4, 72 ) \% greater in the high-Fe formula group, and 35 (95\% CI 7 , 72) \% greater in the Fe drops group. There was no evidence of a change in mean serum transferrin concentration from baseline in the high-Fe formula or Fe drops groups, whereas it significantly increased in the low-Fe formula group, with a mean intervention effect of $-0.1(95 \% \mathrm{CI}-0 \cdot 2,0 \cdot 0) \mathrm{g} / \mathrm{l}$ when both the high-Fe formula group's and Fe drops group's values were compared with those of the low-Fe formula group (Table 2). Serum hepcidin concentrations decreased from baseline in all three study groups (all $P \leq 0 \cdot 022$ ) with no evidence that these changes were related to the intervention $(P=0.908)$. Similarly, despite the significant decrease in mean plasma $\mathrm{Zn}$ concentration from baseline in the high-Fe formula group $(P=0.020)$, there was no evidence of significant intervention-related changes in plasma $\mathrm{Zn}$ concentrations for the three study groups $(P=0.342)$. There was no evidence of intervention effects on mean corpuscular volume, serum Fe concentration or transferrin saturation (Table 2).

At baseline, one infant had Fe-deficient erythropoiesis (Fe drops group). At the end of the study, all infants were Fe sufficient (data not shown in tables). In all, five infants had low plasma $\mathrm{Zn}$ concentrations at baseline (three in the high-Fe formula group and two in the low-Fe formula group) and three at the end of the study (two in the high-Fe formula group and one in the low-Fe formula group) (data not shown in tables). The intervention had no effect on the risk of developing Fe or Zn deficiency (all $P \geq 0 \cdot 760$ ).

\section{Growth}

Within-group comparisons showed that mean weight, length, head circumference and knee-heel length increased from baseline in all three study groups (Table 3; all $P<0 \cdot 001$ ). We found no evidence of intervention effects on weight, length, head circumference or knee-heel length (Table 3; all $P \geq 0.052$ ).

Weight-for-age, length-for-age and head circumference-forage $z$ scores were within the normal range for all infants at all time points (data not shown in tables). Only weight-for-age $z$ scores significantly increased from baseline within each group (high-Fe formula group: 0.17 (95\% CI 0.06, 0.28), $P=0.002$; low-Fe formula group: $0 \cdot 13$ (95\% CI $0 \cdot 03,0 \cdot 23), P=0.013$; and Fe drops group: $0 \cdot 11$ (95\% CI $0 \cdot 00,0 \cdot 21), P=0 \cdot 046)$. Head circumference-for-age $z$ scores increased from baseline in the low-Fe formula group $(0.14(95 \%$ CI $0.05,0.22), P=0.002)$ and the Fe drops group $(0 \cdot 11$ (95\% CI $0 \cdot 02,0 \cdot 21), P=0 \cdot 018)$ but not in the high-Fe formula group $(0.01$ (95\% CI $-0 \cdot 10,0 \cdot 11)$, $P=0 \cdot 900)$. We observed no within-group changes for lengthfor-age $z$ scores in any of the three groups (all $P \geq 0 \cdot 232$ ) (data not shown in tables). There was no evidence of intervention effects on weight-for-age $(P=0.708)$, length-for-age $(P=0.734)$ or head circumference-for-age $(P=0 \cdot 142) z$ scores (data not shown in tables).

\section{Iron absorption and utilisation}

There was no evidence that mean fractional Fe absorption or erythrocyte Fe utilisation differed among the three study groups (Table 4; all $P \geq 0.534$ ). Fe absorption was inversely correlated with serum ferritin concentration (Table 5, Fig. 2), such that a $10 \%$ increase in serum ferritin (e.g. an increase from 60 to $66 \mu \mathrm{g} / \mathrm{l}$ ) corresponded to a $3.9 \%$ decrease in Fe absorption in the high-Fe formula group, a $5 \cdot 6 \%$ decrease in the low-Fe formula group and a $4.8 \%$ decrease in the Fe drops group. Fe absorption was also inversely correlated with serum hepcidin concentration (Table 5, Fig. 3), with each $10 \%$ increase in serum hepcidin (e.g. an increase from 40 to $44 \mu \mathrm{g} / \mathrm{l}$ ) relating to a $2.6 \%$ decrease in Fe absorption in the high-Fe formula group, a $6.5 \%$ decrease in the low-Fe formula group and a $5.0 \%$ decrease in the Fe drops group. In the low-Fe formula group only, Fe absorption was positively associated with serum $\mathrm{Fe}$ concentration, serum transferrin concentration and transferrin saturation (Table 5). The associations between Fe absorption and $\mathrm{Hb}$ concentration and mean corpuscular volume were not significant in any of the intervention groups (Table 5; all $P \geq 0 \cdot 216$ ). Fe utilisation was negatively correlated with mean corpuscular volume only in the low-Fe formula group $(r-0.541$, $P=0 \cdot 011, n 21)$. Fe utilisation did not significantly correlate with $\mathrm{Hb}$, serum ferritin, serum $\mathrm{Fe}$, serum transferrin, transferrin saturation or serum hepcidin in any of the three groups (all $P \geq 0 \cdot 071$; data not shown in the tables).

\section{Zinc absorption}

There was no evidence that mean fractional $\mathrm{Zn}$ absorption differed among the three study groups (Table $4 ; P=0 \cdot 284$ ). 
Table 2. Adjusted means at baseline, day 31 and day 45 with estimates of intervention effect for $\mathrm{Hb}$, mean corpuscular volume, serum ferritin, serum iron, serum transferrin, transferrin saturation, serum hepcidin and plasma zinc in the three study groups*

(Arithmetic/geometric means and $95 \%$ confidence intervals)

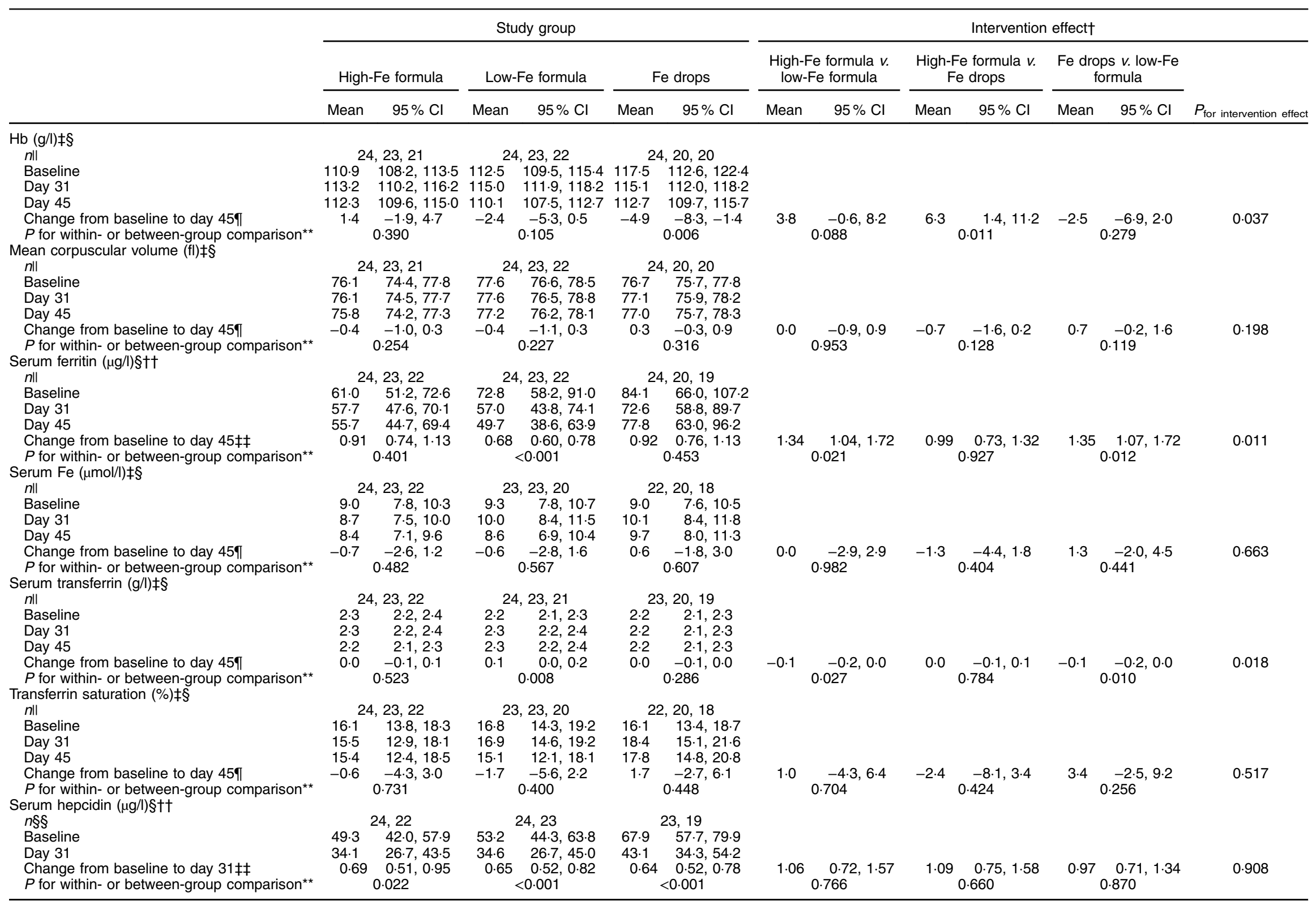




\section{Discussion}

This is the first study to investigate whether the mode of oral Fe administration or the amount of Fe habitually consumed will affect Fe absorption, Fe utilisation and $\mathrm{Zn}$ absorption in healthy, term, predominantly formula-fed, Fe-sufficient infants. We measured intestinal Fe absorption and systemic Fe utilisation directly by using both an oral and an intravenous tracer. This study showed that the type of Fe consumed, whether provided as an oral supplement or as a fortificant in infant formula daily for $45 \mathrm{~d}$, did not affect Fe absorption, Fe utilisation or $\mathrm{Zn}$ absorption in infants. We also found no evidence that high intakes of fortification Fe compared with low intakes had an effect on these parameters.

Our results indicate that in well-nourished, predominantly formula-fed, Fe-sufficient infants Fe stores, rather than the mode of oral $\mathrm{Fe}$ administration or the habitual amount of $\mathrm{Fe}$ consumed, play a more important role in the regulation of $\mathrm{Fe}$ absorption. Fe stores, as determined by serum ferritin, were inversely correlated with Fe absorption and explained between 35 and $62 \%$ of its total variability across the three study groups. This is supported by our previous research, which has shown that low Fe stores up-regulate Fe absorption from infant formula in healthy, formula-fed infants ${ }^{(55)}$, and other studies that have shown that Fe absorption from an Fe supplement is inversely related to infants' $\mathrm{Fe}$ stores ${ }^{(56)}$. In addition, we found evidence for a moderate-to-strong negative correlation between $\mathrm{Fe}$ absorption and serum hepcidin in all three groups in the current study. Hepcidin, a hormone produced primarily by the liver in response to high plasma $\mathrm{Fe}$ and inflammation ${ }^{(57,58)}$, regulates Fe absorption and its distribution to tissues ${ }^{(58)}$. Hepcidin binds to the Fe exporter ferroportin causing its degradation, and thus inhibiting efflux of Fe into plasma ${ }^{(58)}$. Hepcidin may also reduce Fe absorption by inhibiting the expression of enterocyte divalent metal ion transporter $1^{(59)}$. In contrast, Fe deficiency, hypoxia and erythropoietic activity down-regulate hepcidin production, which results in an increase in Fe absorption ${ }^{(60)}$. Except for formula and Fe drops intakes, no additional dietary data were available in the current study. However, as infants were not permitted to consume foods fortified with Fe or foods containing animal tissue, and as we provided all foods to be consumed during the study, it can be assumed that all or most of the Fe consumed during the trial was provided by the interventions. As these $\mathrm{Fe}$ intakes were within a very narrow range in each group, we did not investigate the correlations between dietary $\mathrm{Fe}$ intakes and $\mathrm{Fe}$ absorption, $\mathrm{Fe}$ stores or serum hepcidin. Nevertheless, we have previously shown that $\mathrm{Fe}$ intakes are not associated with either Fe absorption from infant formula or Fe stores in healthy, formulafed infants ${ }^{(55)}$.

Fractional Fe absorption from infant formula in our study was comparable with previous reports ${ }^{(35,61-63)}$. Although daily consumption of approximately $500 \mathrm{ml}$ of low-Fe formula (i.e. $1.2 \mathrm{mg} \mathrm{Fe} / \mathrm{d}$ ) for 1.5 months as the primary source of Fe resulted in reduced $\mathrm{Fe}$ stores and increased serum transferrin concentrations, all infants in the low-Fe formula group were Fe sufficient at the end of the study. However, if the low-Fe formula were to be consumed in the long term in the quantities 
Table 3. Adjusted means at baseline, day 31 and day 45 with estimates of intervention effect for weight, length, head circumference and knee-heel length in the three study groups (Arithmetic means and $95 \%$ confidence intervals)

\begin{tabular}{|c|c|c|c|c|c|c|c|c|c|c|c|c|c|}
\hline & \multicolumn{6}{|c|}{ Study group } & \multicolumn{6}{|c|}{ Intervention effect† } & \multirow[b]{3}{*}{$P_{\text {for intervention effect }}$} \\
\hline & \multicolumn{2}{|c|}{ High-Fe formula } & \multicolumn{2}{|c|}{ Low-Fe formula } & \multicolumn{2}{|c|}{ Fe drops } & \multicolumn{2}{|c|}{$\begin{array}{l}\text { High-Fe formula } v \text {. low-Fe } \\
\text { formula }\end{array}$} & \multicolumn{2}{|c|}{$\begin{array}{l}\text { High-Fe formula } v \text {. Fe } \\
\text { drops }\end{array}$} & \multicolumn{2}{|c|}{$\begin{array}{l}\text { Fe drops } v \text {. low-Fe } \\
\text { formula }\end{array}$} & \\
\hline & Mean & $95 \% \mathrm{Cl}$ & Mean & $95 \% \mathrm{Cl}$ & Mean & $95 \% \mathrm{Cl}$ & Mean & $95 \% \mathrm{Cl}$ & Mean & $95 \% \mathrm{Cl}$ & Mean & $95 \% \mathrm{Cl}$ & \\
\hline \multicolumn{14}{|l|}{ Weight $(\mathrm{kg})$} \\
\hline$n \ddagger$ & \multicolumn{2}{|c|}{$24,22,23$} & \multicolumn{2}{|c|}{$24,23,23$} & \multicolumn{2}{|c|}{$24,20,20$} & & & & & & & \\
\hline Baseline & 8.0 & $7 \cdot 6,8.4$ & $8 \cdot 3$ & $7 \cdot 9,8.6$ & 8.4 & $8 \cdot 1,8 \cdot 7$ & & & & & & & \\
\hline Day 31 & 8.5 & $8 \cdot 1,8 \cdot 9$ & 8.8 & $8.4,9.1$ & 8.9 & $8 \cdot 6,9 \cdot 2$ & & & & & & & \\
\hline Day 45 & 8.7 & $8.4,9.1$ & 9.0 & $8.6,9.4$ & $9 \cdot 1$ & $8.8,9.4$ & & & & & & & \\
\hline Change from baseline to day $45 \S$ & 0.7 & $0.6,0 \cdot 8$ & 0.8 & $0.6,0.9$ & 0.7 & $0.6,0.8$ & 0.0 & $-0.2,0.1$ & 0.0 & $-0.1,0.1$ & 0.0 & $-0.2,0.1$ & 0.917 \\
\hline$P$ for within- or between-group comparisonll & \multicolumn{2}{|c|}{$<0.001$} & \multicolumn{2}{|c|}{$<0.001$} & \multicolumn{2}{|c|}{$<0.001$} & \multirow{2}{*}{\multicolumn{2}{|c|}{0.721}} & \multicolumn{2}{|c|}{0.956} & \multicolumn{2}{|c|}{0.696} & \\
\hline \multicolumn{12}{|l|}{ Length $(\mathrm{cm})$} & & \\
\hline$n \pi$ & \multicolumn{2}{|c|}{24,23} & \multicolumn{2}{|c|}{24,23} & \multicolumn{2}{|c|}{24,20} & & & & & & & \\
\hline Baseline & $67 \cdot 4$ & $66.5,68 \cdot 3$ & 68.0 & $67 \cdot 2,68 \cdot 8$ & 68.1 & $67.3,68.9$ & & & & & & & \\
\hline Day 45 & $70 \cdot 0$ & $69.1,70 \cdot 8$ & $70 \cdot 8$ & $69.8,71 \cdot 7$ & $70 \cdot 9$ & $70 \cdot 0,71 \cdot 7$ & & & & & & & \\
\hline Change from baseline to day $45 \S$ & $2 \cdot 5$ & $2 \cdot 2,2 \cdot 9$ & \multirow{2}{*}{\multicolumn{2}{|c|}{$\begin{array}{c}2 \times 0 \\
<0.001\end{array}$}} & $2 \cdot 8$ & $2 \cdot 4,3 \cdot 2$ & -0.3 & $-0.8,0.3$ & $-0 \cdot 3$ & $-0.9,0.3$ & 0.0 & $-0.6,0.6$ & 0.556 \\
\hline$P$ for within- or between-group comparisonll & \multicolumn{2}{|c|}{$<0.001$} & & & \multicolumn{2}{|c|}{$<0.001$} & \multirow{2}{*}{\multicolumn{2}{|c|}{0.345}} & \multicolumn{2}{|c|}{0.369} & & 0.991 & \\
\hline Head circumference $(\mathrm{cm})$ & & & & & & & & & & & & & \\
\hline$n$ m & & 24,23 & & 24,22 & & 24,20 & & & & & & & \\
\hline Baseline & 43.8 & $43.4,44.3$ & $44 \cdot 1$ & $43.6,44.5$ & 44.3 & $43.9,44.8$ & & & & & & & \\
\hline Day 45 & 44.9 & $44 \cdot 4,45 \cdot 3$ & $45 \cdot 3$ & $44 \cdot 8,45 \cdot 8$ & $45 \cdot 5$ & $45 \cdot 1,46 \cdot 0$ & & & & & & & \\
\hline Change from baseline to day $45 \S$ & 1.0 & $0.9,1 \cdot 1$ & 1.2 & $1 \cdot 1,1 \cdot 3$ & 1.2 & $1 \cdot 1,1 \cdot 3$ & -0.2 & $-0.4,0.0$ & -0.2 & $-0.4,0.0$ & 0.0 & $-0.2,0.1$ & 0.052 \\
\hline$P$ for within- or between-group comparisonll & & 0.001 & & $<0.001$ & & 0.001 & & 0.022 & & 0.046 & & 0.709 & \\
\hline Knee-heel length $(\mathrm{mm})$ & & & & & & & & & & & & & \\
\hline$n \pi$ & & 23,23 & & 24,23 & & 24,20 & & & & & & & \\
\hline Baseline & $66 \cdot 0$ & $62 \cdot 6,69 \cdot 4$ & 66.6 & $63 \cdot 8,69 \cdot 3$ & $66 \cdot 4$ & $63 \cdot 6,69 \cdot 2$ & & & & & & & \\
\hline Day 45 & $75 \cdot 0$ & $72 \cdot 3,77 \cdot 7$ & 76.5 & $73.5,79.6$ & $75 \cdot 8$ & $72 \cdot 6,78.9$ & & & & & & & \\
\hline Change from baseline to day $45 \S$ & $9 \cdot 0$ & $7 \cdot 4,10 \cdot 6$ & $10 \cdot 0$ & $8 \cdot 3,11 \cdot 7$ & 9.4 & $7 \cdot 7,11 \cdot 0$ & $-1 \cdot 0$ & $-3 \cdot 3,1 \cdot 4$ & -0.4 & $-2 \cdot 7,1 \cdot 9$ & -0.6 & $-2 \cdot 9,1 \cdot 8$ & 0.724 \\
\hline$P$ for within- or between-group comparisonll & & 0.001 & & $<0.001$ & & 0.001 & & 0.424 & & 0.751 & & 0.632 & \\
\hline
\end{tabular}

* All estimates are from linear random-intercept models with robust standard errors adjusted for sex.

† The intervention effect is baseline to day 45 change in one study group minus baseline to day 45 change in another study group.

$\mp n$ at baseline, $n$ at day $31, n$ at day 45 .

$\S$ Expressed as a difference.

II The within-group comparison is baseline to day 45 change within each study group. The between-group comparison is the intervention effect as described in footnotet.

I $n$ at baseline, $n$ at day 45 . 
Table 4. Absorption of iron (from an 8.1 or $8.3 \mathrm{mg}$ dose) and zinc (from a 2.4 or $2.5 \mathrm{mg}$ dose) in healthy, 7-month-old, Swedish infants habitually consuming high-iron formula, low-iron formula or iron drops ${ }^{\star}$ (Geometric/arithmetic means and $95 \%$ confidence intervals)

\begin{tabular}{|c|c|c|c|c|c|c|c|c|c|c|}
\hline & \multicolumn{9}{|c|}{ Study group } & \multirow[b]{3}{*}{$P_{\text {for group comparison }}$} \\
\hline & \multicolumn{3}{|c|}{ High-Fe formula } & \multicolumn{3}{|c|}{ Low-Fe formula } & \multicolumn{3}{|c|}{ Fe drops } & \\
\hline & $n$ & Mean & $95 \% \mathrm{Cl}$ & $n$ & Mean & $95 \% \mathrm{Cl}$ & $n$ & Mean & $95 \% \mathrm{Cl}$ & \\
\hline Fractional Fe absorption (\%)† & 22 & $6 \cdot 8$ & $5 \cdot 8,7.9$ & 22 & 7.4 & $5.8,9.5$ & 19 & $7 \cdot 7$ & $6 \cdot 5,9 \cdot 2$ & 0.534 \\
\hline Erythrocyte Fe utilisation (\%)† & 22 & 88.8 & $83 \cdot 7,94 \cdot 2$ & 22 & $86 \cdot 3$ & $78 \cdot 6,94.8$ & 19 & 88.6 & $84 \cdot 7,92 \cdot 6$ & 0.865 \\
\hline Fractional $\mathrm{Zn}$ absorption (\%)‡ & 22 & $32 \cdot 1$ & $29 \cdot 7,34.5$ & 19 & 29.9 & $27 \cdot 1,32 \cdot 7$ & 19 & $32 \cdot 7$ & $30.4,35.0$ & 0.284 \\
\hline
\end{tabular}

* All estimates are from linear regression models with robust standard errors.

$\dagger$ Values are geometric means.

$\ddagger$ Values are arithmetic means.

Table 5. Univariate correlations between iron absorption and iron status indices in healthy, 7-month-old, Swedish infants habitually consuming high-iron formula, low-iron formula or iron drops ( $\beta$-Coefficients and $95 \%$ confidence intervals)

\begin{tabular}{|c|c|c|c|c|c|c|c|c|c|c|c|c|c|c|c|}
\hline & \multicolumn{15}{|c|}{ Log Fe absorption (\%) } \\
\hline & \multicolumn{5}{|c|}{ High-Fe formula } & \multicolumn{5}{|c|}{ Low-Fe formula } & \multicolumn{5}{|c|}{ Fe drops } \\
\hline & $n$ & $\beta$ & $95 \% \mathrm{Cl}$ & $R^{2}$ & $P_{\text {for } \beta}$ & $n$ & $\beta$ & $95 \% \mathrm{Cl}$ & $R^{2}$ & $P_{\text {for } \beta}$ & $n$ & $\beta$ & $95 \% \mathrm{Cl}$ & $R^{2}$ & $P_{\text {for } \beta}$ \\
\hline $\mathrm{Hb}(\mathrm{g} / \mathrm{l}) \dagger$ & 21 & -0.001 & $-0.025,0.023$ & 0.001 & 0.924 & 21 & 0.021 & $-0.014,0.056$ & 0.079 & 0.216 & 16 & -0.002 & $-0.040,0.037$ & 0.001 & 0.919 \\
\hline Mean corpuscular volume (fl) $\dagger$ & 21 & -0.022 & $-0.063,0.019$ & 0.063 & 0.273 & 21 & -0.036 & $-0.175,0.103$ & 0.015 & 0.596 & 16 & -0.035 & $-0.105,0.034$ & 0.079 & 0.292 \\
\hline Log serum ferritin $(\mu \mathrm{g} / /) \ddagger$ & 22 & -0.415 & $-0.680,-0.149$ & 0.347 & 0.004 & 22 & -0.609 & $-0.918,-0.300$ & 0.458 & 0.001 & 19 & -0.512 & $-0.718,-0.307$ & 0.620 & $<0.001$ \\
\hline Serum Fe $(\mu \mathrm{mol} / \mathrm{l}) \dagger$ & 21 & 0.015 & $-0.033,0.063$ & 0.022 & 0.526 & 21 & 0.080 & $0.025,0.136$ & 0.327 & 0.007 & 16 & 0.011 & $-0.046,0.068$ & 0.012 & 0.683 \\
\hline Serum transferrin $(g / l) \dagger$ & 21 & 0.076 & $-0.575,0.727$ & 0.003 & 0.809 & 21 & 0.820 & $0.042,1.597$ & 0.204 & 0.040 & 16 & 0.605 & $-0.090,1.300$ & 0.199 & 0.083 \\
\hline Transferrin saturation (\%)† & 21 & 0.006 & $-0.018,0.030$ & 0.013 & 0.630 & 21 & 0.044 & $0.003,0.086$ & 0.208 & 0.038 & 16 & -0.002 & $-0.032,0.028$ & 0.001 & 0.904 \\
\hline Log serum hepcidin $(\mu \mathrm{g} / \mathrm{l}) \dagger$ & 21 & -0.280 & $-0.548,-0.011$ & 0.200 & 0.042 & 21 & -0.710 & $-1.051,-0.368$ & 0.500 & $<0.001$ & 16 & -0.540 & $-0.829,-0.250$ & 0.533 & 0.001 \\
\hline
\end{tabular}

* All estimates are from linear regression models. Fe indices were measured on day 31

† Infants with a C-reactive protein concentration $>5 \mathrm{mg} / \mathrm{l}$ or a missing value on day 31 were excluded: $n 1$ (missing value for C-reactive protein) in the high-Fe formula group, $n 1$ (C-reactive protein $>5 \mathrm{mg} / \mathrm{l})$ in the low-Fe formula group and $n 3$ ( $n$ 1, missing value for C-reactive protein; $n 2$, C-reactive protein $>5 \mathrm{mg} / \mathrm{l})$ in the $\mathrm{Fe}$ drops group for $\mathrm{Hb}$, mean corpuscular volume, serum Fe, serum transferrin and transferrin saturation; $n 0$ in the high-Fe formula group, $n 1$ (C-reactive protein $>5 \mathrm{mg} / \mathrm{l})$ in the low-Fe formula group and $n 2$ (C-reactive protein $>5 \mathrm{mg} / \mathrm{l})$ in the Fe drops group for serum hepcidin.

‡ Values were corrected for infection ${ }^{(53)}$. 


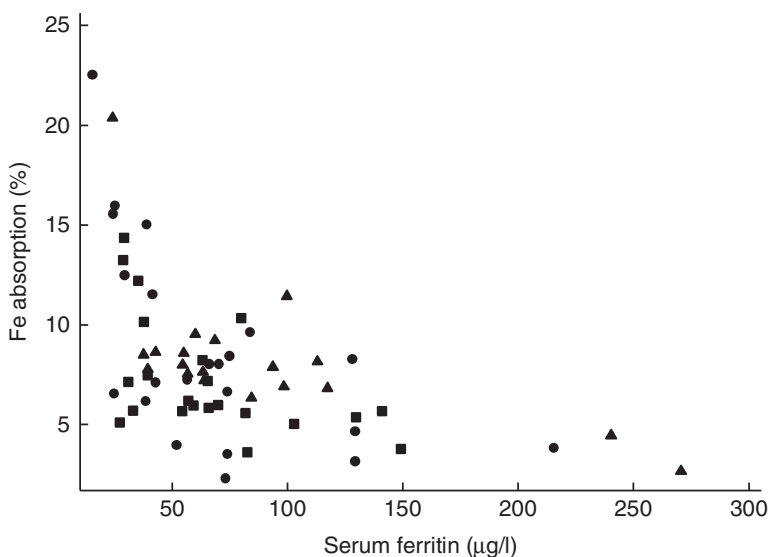

Fig. 2. Scatter plot depicting the relationship between fractional iron absorption and serum ferritin concentration (measured on day 31 ) in healthy, 7-month-old, Swedish infants habitually consuming high-iron formula $(\square, n 22)$, low-iron formula $(\mathbf{O}, n 22)$ or iron drops $(\boldsymbol{\Lambda}, n$ 19). Serum ferritin concentrations were corrected for infection for all infants with a C-reactive protein concentration $>5 \mathrm{mg} / /^{(53)}$. Linear regression on log-transformed values showed a negative correlation between fractional iron absorption and serum ferritin concentration across the three groups $(r-0.64, P<0.001, n 63)$

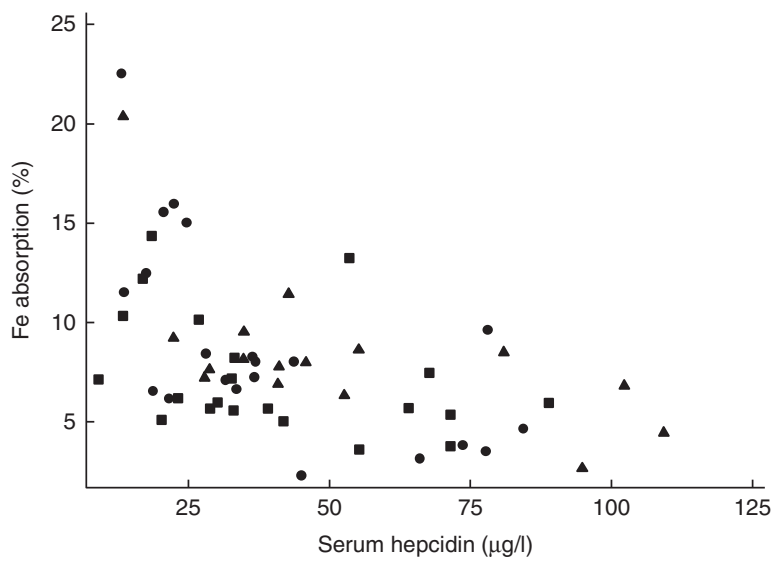

Fig. 3. Scatter plot depicting the relationship between fractional iron absorption and serum hepcidin concentration (measured on day 31) in healthy, 7-month-old, Swedish infants habitually consuming high-iron formula $(\square, n 21)$, low-iron formula $(\boldsymbol{O}, n 21)$ or iron drops $(\boldsymbol{\Lambda}, n$ 16). Infants with an elevated C-reactive protein concentration ( $>5 \mathrm{mg} / \mathrm{l}$ ) were excluded. Linear regression on log-transformed values showed a negative correlation between fractional iron absorption and serum hepcidin concentration across the three groups $(r-0.59, P<0.001, n 58)$.

observed in our study and in the absence of Fe-rich foods, it is unlikely that it would provide sufficient Fe to maintain adequate Fe status in infancy - a conclusion in line with recent recommendations on fortification levels of infant and follow-on formulae ${ }^{(64)}$.

Few studies have determined Fe availability to infants from supplements. The $7.7 \% \mathrm{Fe}$ absorption from Fe drops in our study is similar to that of $7 \cdot 6 \%$ found by Heinrich et al. ${ }^{(65)}$ who administered $10 \mathrm{mg}$ of ferrous sulphate to $1-18$-month-old Fe-sufficient infants and similar to that of $6 \cdot 6-8 \cdot 5 \%$ from $3 \mathrm{mg}$ of ferrous sulphate previously found by our group in 6-9-monthold Fe-sufficient infants ${ }^{(66)}$. In contrast, at $13.7 \%$, Fe absorption from $5 \mathrm{mg}$ of ferrous sulphate appeared to be higher in 13-month-old children in the study by Abrams et al. ${ }^{(56)}$ compared with ours; however, the infants had poorer Fe status compared with the infants in our study. Furthermore, the supplement in the study by Abrams et al. ${ }^{(56)}$ was administered with apple juice that contained ascorbic acid at a 3:1 molar ratio of ascorbic acid:Fe, which could also help explain the higher Fe absorption in their study compared with ours. The addition of ascorbic acid at a molar ratio of $\geq 2: 1$ of ascorbic acid:Fe has been shown to enhance the absorption of Fe from ferrous sulphate $^{(67)}$. In our study, the Fe drops were administered $2 \mathrm{~h}$ after the ingestion of $150 \mathrm{ml}$ of the formula with no added $\mathrm{Fe}$ (131.3 $\mathrm{mg}$ ascorbic acid/l) and $\geq 1 \mathrm{~h}$ before the next meal was consumed. As the formula would have emptied from the stomach after $2 \mathrm{~h}^{(68)}$ and the drops would have been absorbed before the next meal was provided, it is unlikely that the ascorbic acid in the formula would have interacted with the $\mathrm{Fe}$ drops. Fomon et al. ${ }^{(69)}$ found that only $4.4 \%$ of $\mathrm{Fe}$ was incorporated into erythrocytes in 2-month-old formula-fed infants from $8 \mathrm{mg}$ ferrous sulphate administered with ascorbic acid at a 1:1 molar ratio of ascorbic acid:Fe.

It is still uncertain whether the current study lends support to our previous report that fortification Fe is primarily utilised for $\mathrm{Hb}$ synthesis ${ }^{(14)}$. The consumption of $6.4 \mathrm{mg}$ of fortification $\mathrm{Fe}$ per day resulted in a $6.3 \mathrm{~g} / \mathrm{l}$ higher $\mathrm{Hb}$ concentration compared with that achieved with Fe drops and does appear to confirm the earlier observation. Although the high-Fe formula group consumed $0.6 \mathrm{mg} / \mathrm{d}$ more Fe from the intervention compared with the $\mathrm{Fe}$ drops group, this is not enough to explain the differences observed in $\mathrm{Hb}$ concentrations. At $7 \% \mathrm{Fe}$ absorption, $0.6 \mathrm{mg}$ more Fe consumed per day converts to approximately $1.9 \mathrm{mg}(0.04 \mathrm{mg} / \mathrm{d}$ for $45 \mathrm{~d})$ more Fe absorbed by the high-Fe formula group over the 45-d intervention compared with the Fe drops group. This is much less than the amount of additional $\mathrm{Fe}$ needed to raise $\mathrm{Hb}$ concentration by $6.3 \mathrm{~g} / \mathrm{l}$ in an $8 \cdot 5-\mathrm{kg}$ infant with a blood volume of approximately $550 \mathrm{ml}$, which would be approximately $12 \mathrm{mg}$. Nevertheless, there was no evidence that the incorporation of infused $\mathrm{Fe}$ into $\mathrm{Hb}$ was greater in the high-Fe formula group than in the Fe drops group. The labelled Fe infusion was given $30 \mathrm{~min}$ after the isotopic meal, so that the Fe incorporation of the two isotopes would be expected to be similar. In contrast to our previous results ${ }^{(14)}$, we found no evidence that $\mathrm{Fe}$ supplements result in higher Fe stores compared with fortification $\mathrm{Fe}$, which is also unlikely to be explained by the lower amount of total Fe absorbed from the interventions. The Fe drops group absorbed only $1.9 \mathrm{mg}$ less Fe over $45 \mathrm{~d}$ than the high-Fe formula group, and in adults $8-10 \mathrm{mg}$ of additional storage $\mathrm{Fe}$ is needed to increase serum ferritin by $1 \mu \mathrm{g} / \mathrm{l}^{(70)}$.

Fe supplements have been shown to impair $\mathrm{Zn}$ absorption in adults when both minerals are provided together as a supplement in aqueous solutions at a high $\mathrm{Fe}: \mathrm{Zn}$ molar ratio ${ }^{(71)}$. Moreover, Fe supplements given together with $\mathrm{Zn}$ supplements appear to result in reduced plasma $\mathrm{Zn}$ concentrations in infants ${ }^{(28)}$. In contrast, we found no effect of Fe supplements given alone on $\mathrm{Zn}$ absorption or status in infants. This confirms our previous findings of no effect of $\mathrm{Fe}$ supplements on $\mathrm{Zn}$ absorption in infants ${ }^{(29)}$, and is in line with previous research showing that Fe supplements provided to infants alone in the 
range of $7 \cdot 5-30 \mathrm{mg} \mathrm{Fe} / \mathrm{d}$ do not have adverse effects on $\mathrm{Zn}$ status $^{(27,28)}$. The results of our study support the limited research that shows no evidence that consumption of foods fortified with Fe has a negative effect on $\mathrm{Zn}$ absorption ${ }^{(30,32)}$ or $\mathrm{Zn}$ status ${ }^{(32,33)}$ in young children. The absorption of $\mathrm{Zn}$ from the study formulae was similar to that previously reported in infants ${ }^{(36)}$. Dietary nonhaem Fe is transported into enterocytes by the transmembrane protein divalent metal ion transporter $1^{(72)}$, whereas $\mathrm{Zn}$ uptake and transport across enterocytes is regulated by specialised $\mathrm{Zn}$ transporters $^{(73)}$. However, some $\mathrm{Zn}$ transporters (e.g. Znregulated transporter/Fe-regulated transporter-like proteins 8 and 14; ZIP8 and ZIP14) have recently been found to be capable of transporting Fe into mammalian cells ${ }^{(74,75)}$. Therefore, it can be speculated that when an excessive amount of $\mathrm{Fe}$ is consumed together with $\mathrm{Zn}$ in a water solution Fe may inhibit ZIP-mediated $\mathrm{Zn}$ transport, resulting in decreased $\mathrm{Zn}$ absorption and reduced $\mathrm{Zn}$ concentrations. This inhibition would not occur when Fe supplements are ingested alone. In contrast, when Fe is provided in a meal as fortification $\mathrm{Fe}$, it interacts with dietary components that can reduce the number of Fe cations available for absorption compared with supplemental $\mathrm{Fe}$ provided in an aqueous solution, and therefore it does not exert the same negative effect on $\mathrm{Zn}$ absorption or status. Thus, it may be prudent to suggest that in situations when Fe supplements are required they are provided to infants alone or are provided as fortification Fe along with fortification $\mathrm{Zn}$ in infant formula.

Unlike recent reviews showing that $\mathrm{Fe}$ supplementation or fortification may result in reduced weight gain and length in Fe-deficient and Fe-sufficient infants ${ }^{(28,76)}$, we found no evidence that the type or dose of $\mathrm{Fe}$ consumed had a negative effect on physical growth in healthy, Fe-sufficient infants. However, the considerably shorter duration of our study compared with others might have prevented us from observing an effect.

It must be noted that we did not provide placebo drops to the formula groups, which could have potentially biased the results. However, we have shown previously that there is no difference in compliance to placebo or Fe drops in Swedish infants ${ }^{(77)}$. Furthermore, despite the Fe drops group not being blinded, we found no difference among the three groups in the amount of the assigned formula consumed during the trial. Finally, adherence to the allocated intervention was excellent in all groups in the current study.

In summary, Fe can be safely provided to healthy, term, Fe-sufficient infants as either a supplement or a fortificant, within the amounts and duration of intake investigated in our study, as we found no evidence that the mode of oral Fe administration or the amount of Fe habitually consumed altered infant Fe absorption, systemic Fe utilisation, Zn absorption, plasma $\mathrm{Zn}$ or physical growth. As observed previously, consumption of fortification Fe compared with supplemental Fe resulted in a greater $\mathrm{Hb}$ concentration. However, unlike previously shown, consumption of Fe drops did not result in increased Fe stores compared with fortification Fe. Daily intakes of approximately $500 \mathrm{ml}$ of low-Fe formula $(2.3 \mathrm{mg} \mathrm{Fe} / \mathrm{l})$ in the absence of other sources of $\mathrm{Fe}$ are insufficient to maintain $\mathrm{Fe}$ stores in >6-month-old infants. Our results also demonstrate that Fe stores and hepcidin regulate Fe absorption from both Fe supplements and infant formula in Fe-sufficient, predominantly formula-fed infants.

\section{Acknowledgements}

The authors thank Åsa Sundström and Camilla Steinvall Lindberg for participant recruitment and data collection, Monika Brändström for translating all protocols from English to Swedish and Jasmin Tajeri Foman for sample analysis.

This study was supported by the New Zealand Foundation for Research, Science and Technology (grant number UMEA0901 to E. A. S.-G.); ETH Zurich, Switzerland; the Umeå University Foundation; and the Västerbotten County Council (ALF). E. A. S.-G. was supported by a New Zealand Science and Technology Postdoctoral Fellowship from the Foundation for Research, Science and Technology (fellowship grant no. UMEA0901). Semper AB, Sweden, generously provided the study formulae and the fruit- and vegetable-based infant foods. The funders had no role in designing or conducting the study, in the collection, management, analysis or interpretation of the data and had no input into the preparation, review or approval of the manuscript.

The authors' responsibilities were as follows: E. A. S.-G., M. D., O. H., R. F. H., T. L., B. L., C. Z. and I. M. E. designed the study; E. A. S.-G., M. D., O. H. and T. L. conducted the study; C. Z. measured plasma $\mathrm{Zn}$ concentrations and the Fe and $\mathrm{Zn}$ isotopic composition; E. A. S.-G. performed statistical analyses, wrote the paper and took primary responsibility for the final content; and all the authors provided a critical review of the manuscript and read and approved the final version of the manuscript.

O. H. and B. L. are members of the Scientific Advisory Board of Semper and Hero. M. D., O. H., T. L. and B. L. have received research support from Semper and Hero unrelated to the present study. The remaining authors declare no conflicts of interest related to the study.

\section{References}

1. McLean E, Cogswell M, Egli I, et al. (2009) Worldwide prevalence of anaemia, WHO vitamin and mineral nutrition information system, 1993-2005. Public Health Nutr 12, 444-454.

2. Lozoff B, Beard J, Connor J, et al. (2006) Long-lasting neural and behavioral effects of iron deficiency in infancy. Nutr Rev 64, S34-S43.

3. Lind T, Lönnerdal B, Stenlund H, et al. (2003) A communitybased randomized controlled trial of iron and zinc supplementation in Indonesian infants: interactions between iron and zinc. Am J Clin Nutr 77, 883-890.

4. Berger J, Ninh NX, Khan NC, et al. (2006) Efficacy of combined iron and zinc supplementation on micronutrient status and growth in Vietnamese infants. Eur J Clin Nutr 60, 443-454.

5. Iannotti LL, Tielsch JM, Black MM, et al. (2006) Iron supplementation in early childhood: health benefits and risks. $A m \mathrm{~J}$ Clin Nutr 84, 1261-1276.

6. Ziegler EE, Nelson SE \& Jeter JM (2009) Iron status of breastfed infants is improved equally by medicinal iron and ironfortified cereal. Am J Clin Nutr 90, 76-87. 
7. Szymlek-Gay EA, Ferguson EL, Heath ALM, et al. (2009) Foodbased strategies improve iron status in toddlers: a randomized controlled trial. Am J Clin Nutr 90, 1541-1551.

8. Morley R, Abbott R, Fairweather-Tait S, et al. (1999) Iron fortified follow on formula from 9 to 18 months improves iron status but not development or growth: a randomised trial. Arch Dis Child 81, 247-252.

9. Daly A, MacDonald A, Aukett A, et al. (1996) Prevention of anaemia in inner city toddlers by an iron supplemented cows' milk formula. Arch Dis Child 75, 9-16.

10. Gill DG, Vincent S \& Segal DS (1997) Follow-on formula in the prevention of iron deficiency: a multicentre study. Acta Paediatr 86, 683-689.

11. Moffatt ME, Longstaffe S, Besant J, et al. (1994) Prevention of iron deficiency and psychomotor decline in high-risk infants through use of iron-fortified infant formula: a randomized clinical trial. J Pediatr 125, 527-534.

12. Lind T, Seswandhana R, Persson LÅ, et al. (2008) Iron supplementation of iron-replete Indonesian infants is associated with reduced weight-for-age. Acta Paediatr 97, 770-775.

13. Dewey KG, Domellöf M, Cohen RJ, et al. (2002) Iron supplementation affects growth and morbidity of breast-fed infants: results of a randomized trial in Sweden and Honduras. J Nutr 132, 3249-3255.

14. Domellöf M, Lind T, Lönnerdal B, et al. (2008) Effects of mode of oral iron administration on serum ferritin and haemoglobin in infants. Acta Paediatr 97, 1055-1060.

15. Andersson M \& Hurrell RF (2010) Prevention of iron deficiency in infancy, childhood and adolescence. Ann Nestlé Engl 68, 120-131.

16. Brittenham GM, Andersson M, Egli I, et al. (2014) Circulating non-transferrin-bound iron after oral administration of supplemental and fortification doses of iron to healthy women: a randomized study. Am J Clin Nutr 100, 813-820.

17. Britton RS, Leicester KL \& Bacon BR (2002) Iron toxicity and chelation therapy. Int J Hematol 76, 219-228.

18. Kaur D, Peng J, Chinta SJ, et al. (2007) Increased murine neonatal iron intake results in Parkinson-like neurodegeneration with age. Neurobiol Aging 28, 907-913.

19. Lozoff B, Castillo M, Clark KM, et al. (2012) Iron-fortified vs low-iron infant formula: developmental outcome at 10 years. Arch Pediatr Adolesc Med 166, 208-215.

20. Soofi S, Cousens S, Iqbal SP, et al. (2013) Effect of provision of daily zinc and iron with several micronutrients on growth and morbidity among young children in Pakistan: a clusterrandomised trial. Lancet 382, 29-40.

21. Lönnerdal B (2000) Dietary factors influencing zinc absorption. J Nutr 130, 1378S-1383S

22. Brown KH (1998) Effect of infections on plasma zinc concentration and implications for zinc status assessment in lowincome countries. Am J Clin Nutr 68, 425S-429S.

23. Krebs NF, Miller LV \& Hambidge KM (2014) Zinc deficiency in infants and children: a review of its complex and synergistic interactions. Paediatr Int Child Health 34, 279-288.

24. Brown KH, Peerson JM, Baker SK, et al. (2009) Preventive zinc supplementation among infants, preschoolers, and older prepubertal children. Food Nutr Bull 30, S12-S40.

25. Georgieff MK (2007) Nutrition and the developing brain: nutrient priorities and measurement. Am J Clin Nutr 85, 614S-620S.

26. Lim KH, Riddell LJ, Nowson CA, et al. (2013) Iron and zinc nutrition in the economically-developed world: a review. Nutrients 5, 3184-3211.

27. Fischer Walker C, Kordas K, Stoltzfus RJ, et al. (2005) Interactive effects of iron and zinc on biochemical and functional outcomes in supplementation trials. Am J Clin Nutr 82, 5-12.
28. Pasricha SR, Hayes E, Kalumba K, et al. (2013) Effect of daily iron supplementation on health in children aged 4-23 months: a systematic review and meta-analysis of randomised controlled trials. Lancet Glob Health 1, e77-e86.

29. Domellöf M, Hernell O, Abrams SA, et al. (2009) Iron supplementation does not affect copper and zinc absorption in breastfed infants. Am J Clin Nutr 89, 185-190.

30. Fairweather-Tait SJ, Wharf SG \& Fox TE (1995) Zinc absorption in infants fed iron-fortified weaning food. Am J Clin Nutr 62, 785-789

31. Davidsson L, Almgren A, Sandström B, et al. (1995) Zinc absorption in adult humans: the effect of iron fortification. $\mathrm{BrJ}$ Nutr 74, 417-425.

32. Esamai F, Liechty E, Ikemeri J, et al. (2014) Zinc absorption from micronutrient powder is low but is not affected by iron in Kenyan infants. Nutrients 6, 5636-5651.

33. Morgan EJ, Heath A-LM, Szymlek-Gay EA, et al. (2010) Red meat and a fortified manufactured toddler milk drink increase dietary zinc intakes without affecting zinc status of New Zealand toddlers. J Nutr 140, 2221-2226.

34. Gera T, Sachdev HS \& Boy E (2012) Effect of iron-fortified foods on hematologic and biological outcomes: systematic review of randomized controlled trials. Am J Clin Nutr 96 , 309-324.

35. Davidsson L, Ziegler EE, Kastenmayer P, et al. (2000) Erythrocyte incorporation of iron by infants: iron bioavailability from a low-iron infant formula and an evaluation of the usefulness of correcting erythrocyte incorporation values, using a reference dose or plasma ferritin concentrations. BrJ Nutr 84 , 847-853.

36. Abrams SA, Griffin IJ \& Davila PM (2002) Calcium and zinc absorption from lactose-containing and lactose-free infant formulas. Am J Clin Nutr 76, 442-446.

37. Lohman TG, Roche AF \& Martorell R (1988) Anthropometric Standardization Reference Manual. Champaign, IL: Human Kinetics Publications.

38. World Health Organization (2010) WHO Anthro for Personal Computers, Version 3.2.2: Software for Assessing Growth and Development of the World's Children. Geneva: WHO. http:// www.who.int/childgrowth/software/en/ (accessed December 2014).

39. Dainty JR, Roe MA, Teucher B, et al. (2003) Quantification of unlabelled non-haem iron absorption in human subjects: a pilot study. Br J Nutr 90, 503-506.

40. Roe MA, Heath AL, Oyston SL, et al. (2005) Iron absorption in male C282Y heterozygotes. Am J Clin Nutr 81, 814-821.

41. World Health Organization Multicentre Growth Reference Study Group (2006) WHO Child Growth Standards. Length/ Height-for-Age, Weight-for-Age, Weight-for-Length, Weightfor-Height and Body Mass Index-for-Age: Methods and Development. Geneva: WHO.

42. Abrams SA (2008) Assessing mineral metabolism in children using stable isotopes. Pediatr Blood Cancer 50, 438-441.

43. Rustad P, Felding P, Lahti A, et al. (2004) Descriptive analytical data and consequences for calculation of common reference intervals in the Nordic Reference Interval Project 2000. ScandJ Clin Lab Invest 64, 343-370.

44. Walczyk T, Davidsson L, Zavaleta N, et al. (1997) Stable isotope labels as a tool to determine the iron absorption by Peruvian school children from a breakfast meal. Fresenius $J$ Anal Chem 359, 445-449.

45. Bratteby LE (1968) Studies on erythro-kinetics in infancy. XI. The change in circulating red cell volume during the first five months of life. Acta Paediatr Scand 57, 215-224.

46. Wegmüller R, Tay F, Zeder C, et al. (2014) Zinc absorption by young adults from supplemental zinc citrate is comparable 
with that from zinc gluconate and higher than from zinc oxide. J Nutr 144, 132-136.

47. Friel JK, Naake VL Jr, Miller LV, et al. (1992) The analysis of stable isotopes in urine to determine the fractional absorption of zinc. Am J Clin Nutr 55, 473-477.

48. Gibson RS (2005) Principles of Nutritional Assessment, 2nd ed. New York: Oxford University Press.

49. World Health Organization (2001) Iron Deficiency Anaemia: Assessment, Prevention and Control. A Guide for Programme Managers. WHO/NHD/01.3. Geneva: WHO.

50. Domellöf M, Dewey KG, Lönnerdal B, et al. (2002) The diagnostic criteria for iron deficiency in infants should be reevaluated. J Nutr 132, 3680-3686.

51. Saarinen UM \& Siimes MA (1977) Developmental changes in serum iron, total iron-binding capacity, and transferrin saturation in infancy. J Pediatr 91, 875-877.

52. Brown KH, Rivera JA, Bhutta Z, et al. (2004) International Zinc Nutrition Consultative Group (IZiNCG) technical document \#1. Assessment of the risk of zinc deficiency in populations and options for its control. Food Nutr Bull 25, S99-S203.

53. Thurnham DI, McCabe LD, Haldar S, et al. (2010) Adjusting plasma ferritin concentrations to remove the effects of subclinical inflammation in the assessment of iron deficiency: a meta-analysis. Am J Clin Nutr 92, 546-555.

54. Mburu AS, Thurnham DI, Mwaniki DL, et al. (2008) The influence and benefits of controlling for inflammation on plasma ferritin and hemoglobin responses following a multimicronutrient supplement in apparently healthy, HIV + Kenyan adults. J Nutr 138, 613-619.

55. Szymlek-Gay EA, Lönnerdal B, Abrams SA, et al. (2012) alphaLactalbumin and casein-glycomacropeptide do not affect iron absorption from formula in healthy term infants. J Nutr $\mathbf{1 4 2}$, $1226-1231$.

56. Abrams SA, O'Brien KO, Wen J, et al. (1996) Absorption by 1 -year-old children of an iron supplement given with cow's milk or juice. Pediatr Res 39, 171-175.

57. Nemeth E, Tuttle MS, Powelson J, et al. (2004) Hepcidin regulates cellular iron efflux by binding to ferroportin and inducing its internalization. Science 306, 2090-2093.

58. Ganz T (2011) Hepcidin and iron regulation, 10 years later. Blood 117, 4425-4433.

59. Brasse-Lagnel C, Karim Z, Letteron $P$, et al. (2011) Intestinal DMT1 cotransporter is down-regulated by hepcidin via proteasome internalization and degradation. Gastroenterology 140, 1261-1271.

60. Nemeth E \& Ganz T (2009) The role of hepcidin in iron metabolism. Acta Haematol 122, 78-86.

61. Kastenmayer P, Davidsson L, Galan P, et al. (1994) A double stable isotope technique for measuring iron absorption in infants. Br J Nutr 71, 411-424.
62. Fomon SJ, Ziegler EE \& Nelson SE (1993) Erythrocyte incorporation of ingested $58 \mathrm{Fe}$ by 56 -day-old breast-fed and formula-fed infants. Pediatr Res 33, 573-576.

63. Stekel A, Olivares M, Pizarro F, et al. (1986) Absorption of fortification iron from milk formulas in infants. Am J Clin Nutr 43, 917-922.

64. Hernell O, Fewtrell MS, Georgieff MK, et al. (2015) Summary of current recommendations on iron provision and monitoring of iron status for breastfed and formula-fed infants in resourcerich and resource-constrained countries. I Pediatr 167, S40-S47.

65. Heinrich HC, Gabbe EE, Whang DH, et al. (1975) Ferrous and hemoglobin-59Fe absorption from supplemented cow milk in infants with normal and depleted iron stores. $Z$ Kinderbeilkd 120, 251-258.

66. Domellöf M, Lönnerdal B, Abrams SA, et al. (2002) Iron absorption in breast-fed infants: effects of age, iron status, iron supplements, and complementary foods. Am J Clin Nutr 76, 198-204.

67. Hurrell R (2002) How to ensure adequate iron absorption from iron-fortified food. Nutr Rev $\mathbf{6 0}$, S7-S15.

68. Cavell B (1981) Gastric emptying in infants fed human milk or infant formula. Acta Paediatr Scand 70, 639-641.

69. Fomon SJ, Ziegler EE, Nelson SE, et al. (1995) Erythrocyte incorporation of iron by 56 -day-old infants fed a $58 \mathrm{Fe}$-labeled supplement. Pediatr Res 38, 373-378.

70. Zimmermann MB (2008) Methods to assess iron and iodine status. Br J Nutr 99, S2-S9.

71. Sandström B, Davidsson L, Cederblad A, et al. (1985) Oral iron, dietary ligands and zinc absorption. J Nutr 115, 411-414.

72. Garrick MD \& Garrick LM (2009) Cellular iron transport. Biochim Biophys Acta 1790, 309-325.

73. Cousins RJ (2010) Gastrointestinal factors influencing zinc absorption and homeostasis. Int J Vitam Nutr Res 80, 243-248.

74. Jenkitkasemwong S, Wang CY, Mackenzie B, et al. (2012) Physiologic implications of metal-ion transport by ZIP14 and ZIP8. Biometals 25, 643-655.

75. Wang C-Y, Jenkitkasemwong S, Duarte S, et al. (2012) ZIP8 is an iron and zinc transporter whose cell-surface expression is up-regulated by cellular iron loading. $J$ Biol Chem 287, 34032-34043.

76. Sachdev H, Gera T \& Nestel P (2006) Effect of iron supplementation on physical growth in children: systematic review of randomised controlled trials. Public Health Nutr 9 , 904-920.

77. Berglund S, Westrup B \& Domellöf M (2010) Iron supplements reduce the risk of iron deficiency anemia in marginally low birth weight infants. Pediatrics 126, e874-e883. 